\title{
1 The Structure of Holocene Climate Change in Mid-Latitude North America
}

3 Bryan N. Shuman and Jeremiah Marsicek

4 Department of Geology \& Geophysics, Roy J. Shlemon Center for Quaternary Studies, University of

5 Wyoming, 1000 E. University Ave, Laramie WY 82070, USA

6

7 Corresponding author contact information:

8 bshuman@uwyo.edu

$9 \quad 307-766-6442$

10

$113 / 16 / 16$

12 Main text: 7068 words

13 


\section{ABSTRACT (198 words)}

15 A sequence of long-term and rapid changes during the Holocene appears in a network of 40 well-

16 resolved paleoclimate datasets from mid-latitude North America, including records of pollen-inferred

17 temperatures, alkenone-derived sea-surface temperatures (SSTs), lake-level changes, dust

18 accumulation, and lake isotopes from Idaho to Maine. Statistical analyses reveal that changes in

19 insolation and the Laurentide Ice Sheet explain $51.7 \%$ of the variance in the records, especially multi-

20 millennial trends, but peak rates of change indicate additional rapid changes at ca. 10.8, 9.4, 8.3, 7.0,

$215.5-5.2,4.7,2.1$, and 0.9 ka. Step changes between 9.4 and 8.3 ka relate to ice sheet dynamics that

22 warmed much of the region, and changes at 5.5 ka were the largest since the demise of the ice sheet.

23 The shift at $5.5 \mathrm{ka}$ initiated widespread cooling and increases in effective moisture, which culminated

24 in the coolest, wettest millennia in most areas after $2.1 \mathrm{ka}$. Replicated evidence from multiple records

25 also shows a spatially-varied set of multi-century fluctuations including 1) low temperatures and high

26 effective moisture at 5.5-4.8 ka in the mid-continent and 2) repeated phases of low SSTs, cool

27 summers, and drought superimposed upon long cooling, moistening trends in eastern North American 28 since $5.5 \mathrm{ka}$.

\section{INTRODUCTION}

32 Efforts to understand Holocene climate change have demonstrated the importance of insolation, ice 33 sheet, and greenhouse gas changes at multi-millennial scales (e.g., COHMAP, 1988; Kaufman et al.,

34 2004; Liu et al., 2014; Marcott et al., 2013; Renssen et al., 2009), but millennial-to-centennial

35 variations and events also shaped Holocene climates (Alley et al., 1997; Booth et al., 2005; deMenocal

36 et al., 2000; Fleitmann et al., 2008; Magny and Haas, 2004; Magny et al., 2006; Martin-Puertas et al.,

37 2012; Neff et al., 2001; van Geel et al., 2000). Changes composed smooth temporal trends when

38 averaged at global-to-continental scales (Marcott et al., 2013), but long waves in the westerlies 
guarantee that many mid-latitude changes were expressed as mosaics of regional anomalies of different

40 sign and magnitude (Donders et al., 2008; Morrill et al., 2013; Renssen et al., 2009) and with different multivariate characteristics (Morrill et al., 2013; Rach et al., 2014). Diagnosing the full spectrum of Holocene climate changes, therefore, requires comparisons of many complementary paleoclimate records (Mayewski et al., 2004; Wanner et al., 2011, 2008).

In mid-latitude North America, Holocene climate history differed from that of other regions because of a specific combination of long-term trends (e.g., Bartlein et al., 2011; Viau et al., 2006), regime shifts (Shuman et al., 2002; Williams et al., 2010), and variability at annual to multi-centennial scales (Booth et al., 2006; Grimm et al., 2011; Nelson et al., 2011; Newby et al., 2014; Nichols and Huang, 2012). Here, we attempt to integrate multiple temperature, moisture, and isotopic records to describe the most coherent and robust Holocene paleoclimate signals. We use a network of 40 records to document the relative sequence and covariance, i.e., the structure, of temperature and moisture trends, steps, and events from the Rocky Mountains to the Atlantic coast (Fig. 1). We define trends as progressive, multimillennial changes; steps as non-reversing changes that took place within centuries; and events as temporary (reversing) fluctuations that lasted less than $\sim 1000$ years.

Individual datasets cannot detect all regionally-significant changes because any given change may be spatially heterogeneous and may not affect all sites (Cook and Krusic, 2004; Mann et al., 2009; Williams et al., 2010). Likewise, individual parameters (e.g., temperature or drought severity) cannot represent the full complexity of the climate history (Rach et al., 2014). For these reasons, we follow

60 Alley’s (2003) suggestion to use multiply-replicated, multi-parameter analyses as a way to improve 61 reliability and confidence in the paleoclimate signals. We focus on four types of records that have been 62 consistently measured at multiple locations and that can be readily interpreted as representing key 63 climate variables. In particular, we use the multi-site, multi-record evidence to evaluate when and 
where steps and events punctuated the well-documented long trends.

65

66 To do so, we produce regional and sub-regional averages (stacks) of 1) pollen- and alkenone-inferred

67 summer temperatures; 2) quantified lake-level changes; 3) relative dust accumulation rates; and 4)

68 lake-sediment isotopic values. We use the regional and sub-regional means of each data type to filter

69 local ecological, hydrological, or geochemical factors and to clarify common climate signals that

70 extend beyond individual sites. Correlations among variables further confirm where and when

71 important climate signals have been detected by multiple independent approaches. We calculate rates of

72 change and use principal components to identify common periods and patterns of changes. The relative

73 significance and sequences of change can help to diagnose the North American climate dynamics that

74 were important for ecological, geomorphic, and cultural changes during the Holocene (e.g., Foster et

75 al., 2006; Halfen and Johnson, 2013; Kelly et al., 2013; Munoz et al., 2011).

76

\section{2. METHODS}

78

\subsection{Data}

79 Our analysis uses a network of 40 records from 38 sites between the Rocky Mountains (Colorado, 80 Wyoming, Idaho) and the North Atlantic coast (including two marine records from off Virginia and

81 Nova Scotia). They represent the region influenced by Atlantic-derived moisture and air masses in mid-

82 latitude North America, and span the west-to-east North American moisture gradient (Bryson, 1966;

83 Liu et al., 2010). Annual temperatures vary little across the region today, but seasonal temperature

84 differences decline and annual precipitation increases from $<400 \mathrm{~mm}$ to $>1100 \mathrm{~mm}$ from west to east

85 (NCDC, 1994). Mean July temperatures do not vary systematically by longitude within the study area,

86 but range from $18^{\circ} \mathrm{C}$ at the northern sites to $24^{\circ} \mathrm{C}$ in the south (NCDC, 1994).

87

88 Most records were either generated by us or were publically available (Fig. 1; Table 1). Each was 
required to have spanned from $<0.6$ to $>10.0$ ka for the purpose of consistent statistical power

90 throughout the Holocene, and as a result, we excluded some relevant and well-resolved isotope datasets

91 that did not extend to before 9 ka (e.g., Anderson, 2012; Smith et al., 2002). To evaluate sub-regional

92 differences, we divided the datasets into four sub-regions: western (Colorado to North Dakota); west-

93 central (South Dakota to Illinois); east-central (Ontario); and eastern (New York to Maine). Groupings

94 were predominantly geographical, but were modified based on clusters of records identified using

95 principal components analyses (see Section 2.2).

\section{$97 \quad$ 2.1.1. Temperature records}

98 Of the 40 records, nineteen document changes in the mean temperature of the warmest month (MTWM). The MTWM records derive from well-resolved pollen-inferred reconstructions (>70 samples/11,000 years) from North Dakota to Maine (Table 1), and are supplemented by a temperature reconstruction based on two pollen records from northern Wyoming (Kelly et al., 2013; Shuman, 2012a) to extend the geographic coverage. We focus on regional averages of the reconstructions because they represent the common temperature signals and average out local ecological influences (e.g., local disturbances), but we also discuss where individual records either deviate from or provide support for the mean patterns.

The reconstructions were generated using a widely applied space-for-time substitution (modern analog) technique (Overpeck et al., 1985), which assigned temperatures to each fossil sample based on comparisons with >4000 modern pollen samples from across North America (Whitmore et al., 2005).

110 We followed methodological suggestions from Williams and Shuman (2008) including a) averaging the

111 MTWM values from the seven best modern analogs for each sample, b) using 64 regionally-split taxa

112 for the comparisons, and c) applying the squared chord distance as the measure of comparison. We 113 place the MTWM reconstructions in the context of other paleoenvironmental records to assess the 
114 coherency of the climate signals and the nature of moisture and isotopic changes that coincided with

115 the regional temperature changes.

116

117 As an additional comparison and to further extend the geographic coverage of temperature records, we

118 also include two sea-surface temperature (SST) reconstructions derived from alkenone

119 paleothermometry from the margin of eastern mid-latitude North America (Sachs, 2007). We linearly

120 detrended (and evaluate the detrending of) the original temperature series, however, because the raw

121 SST reconstructions contain a large magnitude trend that indicates that late-Pleistocene (Younger

122 Dryas) temperatures were $5^{\circ} \mathrm{C}$ greater than today (Sachs, 2007) and that may have resulted from

123 nutrient, light, seasonality, or depth biases in alkenone production (Kim et al., 2004; Prahl et al., 2006).

124 At a minimum, the large trends were not likely representative of conditions on the continent where late-

125 Pleistocene cold is well documented (Levesque et al., 1997; Mott et al., 1986; Peteet et al., 1990), but

126 the additional variability may be relevant and is, therefore, evaluated here.

127

$128 \quad$ 2.1.2. Moisture records

129 Nine records provide quantified estimates of Holocene lake-level changes. Several of the records from

130 closed basin lakes have been used with mass-balance approaches to quantify precipitation minus

131 evapotranspiration (P-E) through time (Marsicek et al., 2013; Newby et al., 2014; Pribyl and Shuman,

132 2014; Shuman et al., 2010), but P-E cannot be easily produced for overflowing lakes (i.e., Upper Big

133 Creek and Lower Paintrock Lakes in Colorado and Wyoming, Table 1) or for the two other effective

134 moisture records used here (relative dust accumulation rates from Elk and Steel Lakes, Minnesota).

135 Therefore, and because the P-E reconstructions are simply linear transformations of the lake-level

136 histories (Pribyl and Shuman, 2014), we transform all of the moisture records to z-scores. Z-scores

137 measure deviations from the Holocene mean of each record in terms of standard deviations, and

138 account for the different units in lake and dust records as well as the different magnitudes of water level 
change in lakes and watersheds of different sizes.

140

141 The lake-level reconstructions all rely on the same technique (Digerfeldt, 1986; Pribyl and Shuman,

142 2014), which uses transects of sediment cores and on-shore sediment profiles (supplemented with

143 geophysical surveys) to track the elevation and lateral position of near-shore sediments as a direct

144 measure of shoreline position. At each lake, sediment characteristics from 2-5 radiocarbon-dated cores

145 from different water depths were systematically analyzed using a decision-tree approach applied in R

146 (R Core Development Team, 2009) to determine intervals containing near-shore sediments

147 (paleoshoreline deposits). Water-level changes were then reconstructed systematically in R based on

148 the changing elevations of the near-shore sediments at each site (Pribyl and Shuman, 2014).

150 The two lake-sediment mineralogy datasets from Minnesota (Dean, 1997; Nelson and Hu, 2008)

151 provide an index of aeolian dust accumulation based on the sediment fraction of fine quartz and

152 feldspars measured by x-ray diffraction (XRD). Aeolian dust accumulation likely reflects regional

153 aridity because low effective moisture (P-E) reduces vegetation cover and facilitates aeolian erosion

154 (Forman et al., 2001; Kohfeld and Harrison, 2000). Because dust flux can relate to aridity in a non-

155 linear fashion (e.g., potential dust-source areas may change exponentially in extent during drought) and

156 because the data are not normally distributed, we log transformed the XRD data for all plots and

157 analyses. Despite potential complexities, such as the role of winds and changing sources of fine

158 particulates (Mason et al., 2003; McKean et al., 2015; Muhs et al., 2008), we use the records because

159 they provide an opportunity to evaluate the fidelity of the signals in replicated records from the same

160 area. They also provide detailed information about the relative sequence of hydroclimate changes in a

161 sub-region without the type of quantitative lake level records used elsewhere.

162 
164 We compare the temperature and moisture records with seven stable hydrogen and oxygen isotope

165 datasets from lake sediments, which are distributed across our four sub-regions. Six stable isotope

166 datasets (Bear, Bison, O’Brien, Crawford, Fayetteville Green, and Grinnell lakes) represent the oxygen

167 isotope composition of bulk carbonate sediments (Anderson, 2011; Bright et al., 2006; Henne and Hu,

168 2010; Kirby et al., 2002; Yu et al., 1997; Zhao et al., 2010), whereas one (Berry Pond) represents the

169 hydrogen isotopic composition of $C_{22} n$-acid, an organic compound primarily derived from emergent

170 aquatic plants (Hou et al., 2007; Shuman et al., 2006). Many interacting hemispheric to local scale

171 processes can influence individual lake-sediment stable isotopes (Gibson and Edwards, 2002; Gibson

172 et al., 2002; Henderson and Shuman, 2009; Jasechko et al., 2013; LeGrande and Schmidt, 2009;

173 Schlaepfer et al., 2014; Smith and Hollander, 1999; Steinman and Abbott, 2013), but networks of lakes

174 can retain important patterns related to climate and atmospheric circulation (e.g., Henderson and

175 Shuman, 2009; Shanahan et al., 2015). As with the other types of records, our comparisons reveal the

176 regional fidelity of the embedded signals.

177

$178 \quad 2.2$ Analyses

179 Regional and sub-regional mean temperature and moisture histories were calculated where multiple

180 records could be averaged. We plot standard errors to show the confidence in the mean patterns of

181 change, but also assessed the signals in combinations of records by also generating means for all

182 factorial combinations of the individual datasets. Doing so reveals the sensitivity of the mean record to

183 inclusion of any individual record and its particular age uncertainties, sample spacing, and

184 reconstruction errors. Likewise, we completed 100 bootstrapped iterations of principal components

185 analysis (PCA) in R to quantify the amount of variance common across 1) all datasets and 2) three

186 categories of data: temperature, effective moisture (lake-level and dust accumulation), and isotope

187 records. To do so, we randomly selected (with replacement) from the relevant pool of records to 
generate 100 random combinations for PCA. We conducted the PCA on correlation matrices except when analyzing temperatures alone. For temperature, the covariance matrix was used to retain the magnitude of the signals in degrees C. We also used the PCA loadings to identify regional groups of correlated datasets and to recognize outliers before calculating regional means of the different

192 variables.

194 We defined abrupt changes as times when the rates of change over 200 year intervals rose above $85 \%$ of the background rates. We computed the rates of change in terms of the absolute change in z-scores from the beginning to end of each 200-year interval. Mean rates were calculated for each data type, and then a mean of the data-type means was used as a summary index to avoid biases associated with differences in the number records of each data type. We focus on the periods of major abrupt changes identified in the summary index, but also use peaks in the rates of change from the different types of records, sub-regions, and principal components to identify periods of abrupt changes as expressed by these other metrics. For this reason, we provide different ages for some changes depending on the metric being discussed.

We also calculated correlations among records, regional and subregional means, and PCA scores to assess the coherency of the signals. We applied linear regression and Granger causality tests in R to further quantify the relationships. Linear models quantify the amount of variance in one time series that can be explained by another or by important forcing functions (i.e., time series of insolation and glacial extent)(Berger and Loutre, 1991; Dyke, 2004), but because autocorrelation within time series data can produce spurious correlations, we use the Granger tests to evaluate whether a given predictor provides more information than expected from autocorrelation alone (Granger, 1969). 
213 used published age models for the isotope, dust, and SST records, but developed age models for

214 temperature and lake level records using Bchron, a Bayesian tool for incorporating calibrated

215 radiocarbon uncertainties and sample spacing into age models (Haslett and Parnell, 2008; Parnell et al., 216 2008). Doing so enabled us to include updated chronological information for some of the sites (Grimm 217 et al., 2009).

\section{RESULTS}

\subsection{Major patterns of temperature, moisture, and isotopic change}

\subsubsection{Mean regional changes}

222 The record of regional mean temperatures (derived from pollen and alkenones) and effective moisture 223 (from lake level and dust flux) confirms that the Holocene climate history of mid-latitude North 224 America included a combination of long-term trends, abrupt shifts, and multi-century events (Fig. 2). 225 Mean temperatures of the warmest month for the region rose progressively by $>1.5^{\circ} \mathrm{C}$ to a maximum at $2267 \mathrm{ka}$ and have since declined by $>0.5^{\circ} \mathrm{C}$ (Fig. 2A). Mean effective moisture levels across the region, 227 however, have only recently achieved their maximum based on Holocene-scale changes in lake levels 228 and dust flux of $>1.5$ sd (Fig. 2B).

Prominent accelerations of the long-term trends decreased temperatures and increased effective moisture at 5.5-4.7 and 2.1-1.8 ka (Fig. 2). The multi-century changes equaled about 50\% of the magnitude of the long-term trends since $7 \mathrm{ka}$, but were $>140 \%$ as rapid. The mean rate of change across all datasets exceeded $85 \%$ of the rates ( $0.26 \mathrm{sd} / 200 \mathrm{yrs})$ seven times: at 10.9-10.5, 9.4, 8.3, 5.5, 5.2, 4.7, and 0.9-0.6 ka (Fig. 3, top panel). During these intervals, abrupt century-scale shifts in temperature and effective moisture (vertical dashed lines, Fig. 2) punctuated the progressive background trends, which had a mean background rate of change of $0.18 \pm 0.09 \mathrm{sd} / 200 \mathrm{yr}$. 
238 Several of the rapid changes cluster in the early Holocene (Fig. 2-4). Effective moisture and

239 temperature increased rapidly by $10.5 \mathrm{ka}$, and then shifted stepwise at ca. 9.3-9.1 and 8.4-8.0 ka

240 respectively. Effective moisture declined stepwise at 9.3-9.1 ka by $0.2 \mathrm{sd} / 200 \mathrm{yr}$, which is more than

241 twice the mean background rate of lake-level change of $0.08 \pm 0.07 \mathrm{sd} / 200 \mathrm{yr}$ and especially prominent

242 in the median of the moisture records (thin black line, Fig. 2B). The step change initiated a new multi-

243 millennial mean that persisted until 6 ka (Fig. 2B). The second principal component of the moisture

244 records emphasizes that the shift represents part of a large moisture change from 9.3 to 7.4 ka (Fig.

245 4B). Temperatures experienced a similar stepwise increase of $0.2^{\circ} \mathrm{C}$ to a new multi-millennial mean at

246 8.4-8.0 ka (Fig. 2A). PCA confirms that temperature changes at 8.4-8.0 ka included both a cool event

247 (Fig. 4A, lower panel) and a step change (Fig. 4A, upper panel).

248 The most prominent interval of anomalously low temperatures developed at 5.5-4.7 ka after the 249 single largest and most coherent increase in effective moisture in the Holocene record (Fig. 2-4). The 250 largest change in the ensemble of stable isotope records also took place at this time (Fig. 4C); PC1 of 251 isotopic records contrasts the distribution of values before 5.2 ka with more recent values. PCA of the 252 temperature records indicates, however, that the net regional cooling at 5.5-4.7 ka may be a 253 combination of two different patterns: peak rates of cooling at many sites by 4.8 ka (Fig. 4A, top) as 254 well as a brief cool event when temperatures were $\sim 0.5^{\circ} \mathrm{C}$ lower than the mid-Holocene mean for ca. 255400 years from 5.2 to 4.8 ka (Fig. 4A, bottom). The highest mid-Holocene rates of mean regional 256 temperature change bracketed this later event (Fig. 3B), and median temperatures reached two minima 257 at 5.5-5.2 and 5.0-4.8 ka (thin black line, Fig 2A).

259 Warming combined with widespread drought at 4.7 ka to end the anomalously cool, wet conditions that 260 began after 5.5 ka (Fig. 2). Afterwards, mean regional temperatures changed little until 2.9 ka, except 261 for a minimum from 3.9-3.5 ka and a maximum at $3.0 \mathrm{ka}$; both events shifted the distribution of boot 262 strapped temperatures (gray lines, Fig. 2A). The extensive drought after 4.7 ka persisted until 4.0 ka 
263 (with median moisture levels reaching a minimum from 4.2-3.9 ka), but the drought was followed by a 264 progressive increase in effective moisture to present (Fig. 2B, 4B). Additional drought episodes at 3.62653.3 and 3.0-2.4 ka had sufficient severity across records to also temporarily decrease the median and 266 mean effective moisture z-scores relative to the long-term increase, but the events did not achieve the 267 magnitude or extent of the aridity reconstructed at 4.7-4.0 ka (Fig. 2B).

Later shifts in both temperature (cooling) and effective moisture (increasing) at 2.6-1.8 ka represent a 270 final acceleration of the long-term trends (Fig. 2, 4), although they were not sufficiently rapid or synchronous to produce major peaks in the mean rates of change (>0.25 sd/200 yrs; Fig. 3). The transitions resulted in the establishment of modern-like conditions for the remainder of the Holocene, except for a prominent warm, dry episode from 0.80-0.35 ka (1150-1600 AD).

\subsubsection{Common signals across variables}

The temperature and moisture datasets share a significant amount of signal at multi-millennial to multi277 century scales despite deriving from different types of records and from different sites. Over the last 7 ka, the mean regional temperature and moisture time series (Fig. 2) correlate significantly $(r=-0.90 ; 1$ sd range $=-0.53$ to -0.95$)$. Granger causality tests indicate that each series contributes significantly more to predicting the other than autocorrelation within either series alone (moisture as a predictor of temperature: $\mathrm{F}=10.86, \mathrm{p}=0.0013$; temperature as a predictor of moisture: $\mathrm{F}=2.96, \mathrm{p}=0.087$ ). Rates simultaneously, although they also confirm differences among the sequences of moisture and temperature changes.

PCA of the entire multivariate dataset reveals that all four data types contribute similarly to the first 
explains 34.9\% of the variance (Fig. 5A), and the second explains an additional $21.0 \%$ (Fig. 5B).

289 Together, they reveal two major long-term patterns: PC1 correlates $(r=0.83)$ with orbitally driven 290 changes in seasonal insolation (red line, Fig. 5A) and PC2 correlates $(r=0.91)$ with the area of the 291 Laurentide Ice Sheet (blue line, Fig. 5B). Removing the insolation trend from PC1 produces residuals 292 that also correlate $(r=0.97)$ with the area of the ice sheet (gray line, Fig. 5B). Linear models show that 293 insolation and ice sheet area explain $69.0 \%$ and $29.2 \%$ of the variance in PC1 respectively; ice sheet area explains $83.0 \%$ of PC2. Insolation and ice sheet area, therefore, explain at least $24.0 \%$ and $27.7 \%$, 295 respectively, of the total variance in our spatially distributed, multivariate dataset.

PC1 and PC2 also show a series of common features at multi-century scales (Fig. 5C-D). Both components show a stepwise deviation from the insolation and ice area trends at $9.3 \mathrm{ka}$, which was progressively reversed over the course of the Holocene by a long trend and a series of rapid steps and 300 fluctuations of $>0.5$ sd at $8.4,7.0,5.3$, and $2.1 \mathrm{ka}$.

301

\subsection{Sub-regional changes}

The major trends, abrupt changes, and multi-century events affected all of our sub-regions in different ways (Fig. 6). In all of the sub-regions, temperature trends after 8 ka correlated significantly but negatively with the moisture trends ( $r=-0.58$ to -0.89 ). As mean regional temperatures declined, effective moisture rose (Fig. 6). For example, correlations and Granger tests indicate that temperature changes at Steel Lake, Minnesota (Fig. 6B, thin black line) usefully predict the effective moisture trends inferred from dust changes there (Fig. 6B, middle row): $r=-0.52 ; \mathrm{F}=9.26, \mathrm{p}=0.0027$.

The independent datasets consistently reconstructed multiple multi-century events (e.g., a midcontinental cold period at ca. 5.5-4.8 ka, Fig. 7), but the sequence of multi-century events and step changes observed in the mean regional record (Fig. 2) does not represent a widely or consistently 
313 expressed signal at sub-regional scales (Fig. 6). Rather, the events and steps in the mean record (Fig. 2)

314 often represent positive interference among sub-regional patterns with different, but overlapping,

315 periods of anomalous conditions. For example, cool events $\left(>0.4^{\circ} \mathrm{C}\right.$ and $\left.>200 \mathrm{yrs}\right)$ interrupted the

316 warming before $8.0 \mathrm{ka}$ at different times in different regions: a) in the west from 9.7-8.5 ka; b) at Steel

317 Lake and other west-central sites at 8.6-8.1 and 8.0-7.5 ka respectively; c) in Ontario at 9.3-8.9 ka; and

318 d) in SSTs at 9.5-9.1 ka (Fig. 6). Some of these events overlap in time and may only differ due to age

319 uncertainties, but others are potentially out of phase with each other (e.g., Fig. 6B). Despite the

320 differences, the data widely record a subsequent step change at 8.2-8.0 ka that produced near stationary

321 maximum temperatures until at least $6.8 \mathrm{ka}$ in central and eastern areas (Fig. 6B-D).

322

323 In the eastern coastal region, the MTWM reconstruction correlates $(r=0.77)$ with the detrended SST

324 record (Fig. 6D). Both indicate warming of $1-2^{\circ} \mathrm{C}$ with important, but different, multi-century

325 fluctuations before $7 \mathrm{ka}$. By contrast, the raw SST reconstructions, which retain a large linear trend

326 (Sachs, 2007), indicate that the early Holocene and Younger Dryas (YD) chronozone (12.7-11.7 ka)

327 were $>5^{\circ} \mathrm{C}$ warmer than today, which is inconsistent with the magnitudes of the various isotopic

328 changes and with the pollen-inferred temperatures from all of the sub-regions (top, Fig. 6). In fact, the

329 southern tier of west-central sites from Pickerel Lake, SD to Chatsworth Bog, IL, were at least as cool

330 as today until after 4.8 ka even though Steel Lake, MN to the north warmed to higher than modern

331 temperatures after 8.2 ka (Fig. 6B). PC1 loadings indicate opposing directions of temperature change

332 (cooling versus warming since $7 \mathrm{ka}$ ) in northern (e.g., Mansell Pond, Maine; Scotian margin SSTs) and

333 southern reconstructions (e.g., Chatsworth Bog, Illinois) as well as a geographically crosscutting zone

334 with small trends (loadings <0.1) from North Dakota and southern Minnesota to Wisconsin and

335 southern Ontario (Table 2).

337 The directions of some major moisture changes also differed between western and eastern areas (Fig. 
6). Lake levels from inland (Fig. 6C) and coastal Massachusetts (Fig. 6D) increased by $>1$ sd before

9.0 and 8.2 ka respectively, but moisture levels in the west rose to an early Holocene maximum by 10

ka and then rapidly declined to their lowest levels of the past 10 ka at 9.3 ka (Fig. 6A). Effective

moisture also declined after an early Holocene maximum (>9.3 ka) in the west-central region based on

short-lived peaks and attendant stepwise increases in dust deposition at 9.3 and $8.2 \mathrm{ka}$ at Elk and Steel

Lakes, MN (Fig. 6B, note inverted scale). The dust records only extend to $<11 \mathrm{ka}$, but their mean

correlates with the mean lake-level record from Wyoming over the common period of record $(\mathrm{r}=-0.57$;

Fig. 6B-C); Granger tests show that the mean dust record contributes significantly to predicting the Wyoming lake changes $(\mathrm{F}=5.25, \mathrm{p}=0.023)$. Taken together the various records show that the eastwest moisture gradient had been weaker than today before ca. 9 ka because effective moisture was low in the east and high in the west. The gradient then steepened as the west dried relative to the east by ca. 8 ka.

\section{$\underline{\text { 3.2.1 Mid-Holocene events }}$}

352 In the west (Fig. 6A) and coastal east (Fig. 6D), stepwise cooling of $>0.4^{\circ} \mathrm{C}$ at $5.7-5.0$ ka marked a permanent end to the period with maximum temperatures, which had ended in Ontario at 7.0-6.8 ka (Fig. 6C). Likewise, oxygen and hydrogen isotope values from Steel Lake, O’Brien Lake, Crawford Pond, Fayetteville Green Lake, and Berry Pond (Henne and Hu, 2010; Kirby et al., 2002; Nelson and Hu, 2008; Shuman et al., 2006; Yu et al., 1997) show rapid stepwise declines in delta values at ca. 5.5 ka (Fig. 4C). Because the changes are equivalent to a $>0.5 \%$ change in $\delta^{18} \mathrm{O}$, the shift would be consistent with cooling of $>0.35^{\circ} \mathrm{C}$ based on the Dansgaard (1964) temperature- $\delta^{18} \mathrm{O}$ relationship although numerous other factors almost certainly also influenced the isotope ratios. The shifts are 
362 In the central region, the change at $5.5 \mathrm{ka}$ initiated a prominent millennial-scale fluctuation in

363 temperature and moisture (Fig. 7). A reduction in dust accumulation, and by inference an increase in

364 effective moisture, at Elk and Steel Lakes, Minnesota, from 5.6-4.8 ka coincided with a reduction in

365 pollen-inferred temperatures in the same region (Fig. 6B), particularly at Sharkey Lake, Lake West

366 Okoboji, and Chatsworth Bog (Fig. 7). Varve counts from Elk Lake indicate that the changes there

367 could have taken place within centuries or less at 5.49-5.39 and 4.81-4.54 varve ka.

The event from 5.6-4.8 ka also included hydroclimatic changes in the other sub-regions (Fig. 6). In the

Rocky Mountain west, a narrowing of the uncertainty around the mean lake-level series indicates a

coherent increase in moisture levels by $>0.8$ sd from 5.8 to $5.1 \mathrm{ka}$ (Fig. 6A). Of all of the moisture

records examined here, only Davis Pond from the inland highlands of western Massachusetts did not rise at this time (Fig. 6C), but it experienced a phase of anomalously low water constrained by similar bracketing ages: 5.7-4.9 ka (Fig. 6C).

\subsubsection{Late Holocene}

Changes after 5.7 ka marked the beginning of cooling and moistening trends in many areas, which persisted until present and were punctuated by a series of multi-century events (Fig. 6). In the coastal east, multi-century moisture variations of the last $>5.7$ ka coincided with terrestrial and marine temperature changes (Fig. 8). Warm/dry and cool/moist deviations from the long-term trends appear to represent the dominant modes of variability. The warm, dry phases became progressively cooler and temperatures and moisture levels equal to the earliest of the intervening cool, wet phases (e.g., 4.6-4.2 ka). 
lake level changes (red line, Fig. 8; $\mathrm{p}<2.2 * 10^{-16}$, adjusted $\mathrm{R}^{2}=0.84$ ). Granger tests spanning the period since 8 ka also show that mean SSTs and MTWM predict each other more than the autocorrelation in each series alone (SST as a predictor of MTWM: $\mathrm{F}=16.16, \mathrm{p}=0.00009$; MTWM as a predictor of SST: $\mathrm{F}=10.88, \mathrm{p}=0.00004)$. The temperatures have a similar relationship to the lake 391 level changes (e.g., MTWM as a predictor of lake level: $\mathrm{F}=5.2, \mathrm{p}=0.024$; lake level as a predictor of 392 MTWM: $\mathrm{F}=7.97, \mathrm{p}=0.0054)$. Consequently, the three different data types from nine different sites in the eastern sub-region contain a well-replicated signal of drought and warming at 4.9-4.6, 4.2-3.9, 2.92.1, and 1.3-1.2 ka.

Sharp cooling at $2.1-1.8 \mathrm{ka}$ of $0.25-0.5^{\circ} \mathrm{C}$ coincided with a rapid rise in water levels ( $\left.>0.25 \mathrm{sd}\right)$, and produced the dominant climate of the Common Era (0-1950 AD). SSTs and MTWMs during the preceding 800 years (the “2.7-ka event” from 2.9-2.1 ka) as well as during a pair of cool, moist periods in the millennium from 3.9 to 2.9 ka were $0.2-0.4^{\circ} \mathrm{C}$ higher than during even the warmest portion of the Common Era (1.5-1.2 ka). Consequently, the Common Era represents the coolest and wettest portion of the last 9.3 ka in the coastal east (Fig. 8) and likely, in much of the study region except possibly in central areas such as Minnesota, Iowa, and Illinois (Fig. 6B).

\section{DISCUSSION}

\subsection{Coherency of the records}

Signals in our dataset confirm that the Holocene climate history of mid-latitude North America included a combination of coherent long-term trends (Fig. 5A-B); regime shifts at ca. 9.3, 8.0, 7.0, 5.3, and 2.1 ka (Fig. 5B-D); and multi-century events, such as at 8.3-8.0, 5.2-4.9, and 1.3-0.8 ka (Fig. 5CD). Many of the trends, steps, and events affected both temperature and effective moisture patterns 410 (Fig. 2, 6, 8), and despite some differences among records, were recorded repeatedly and independently 411 by sediment stratigraphies, geochemical changes, and biotic assemblage changes. The shared signals 
validate the robustness of many of the multi-millennial to multi-centennial features of the records.

413

414 Multi-century variability composes an important part of the spectrum of mid-latitude climate changes

415 (Fig. 8), but some events described in other studies, such as at ca. 4.2 and 2.7 ka (Booth et al., 2005;

416 Martin-Puertas et al., 2012; van Geel et al., 2000; Walker et al., 2012), do not consistently appear as

417 prominent features in our study region (Fig. 2, 4, 6). They may have been a) more important in other

418 parts of the world than mid-latitude North America, b) composed of complex multivariate signals, or c)

419 narrower in spatial extent than the largest events and abrupt changes detected by our rates of change

420 and principal component analyses (Figs. 3-5). Changes and events, such as at 5.6-4.8 ka, stand out

421 more prominently than these events in our sub-regions (e.g., Fig. 6), just as other well-studied events,

422 such as at ca. 8.2 ka (Alley et al., 1997) and 9.3 ka (Fleitmann et al., 2008), appear to have different

423 characteristics here than elsewhere (e.g., manifesting as more consistently as step changes rather than

424 events).

425

426 Common signals exist at low frequencies, in part, because all of the records act as low-pass filters on

427 the climate history via factors such as tree longevity, watershed-scale hydrologic response times, and

428 sediment mixing. None of the archives used here, however, have a substantially greater lag or bias

429 towards low frequency components than the others (e.g., alkenone-, pollen-, and sediment-derived

430 datasets in Fig. 8). Indeed, the comparability of the records reveals that even small climate changes,

431 such as temperature changes of $\sim 0.2^{\circ} \mathrm{C}$, produced meaningful ecological changes that affected both

432 terrestrial vegetation and marine plankton (Fig. 8A-B), while also altering the sediment and

433 geochemical dynamics in small lakes and ponds (Fig. 8C).

435 The comparability of multiple records from within individual sub-regions (e.g., Figs. 7-8) indicates that 436 additional differences among sub-regions (Figs. 6) and variables (Fig. 3-4) likely represent underlying 
437 climatic heterogeneity and structure much like that that exists during modern droughts or other 438 variations. The records examined here differ most often, and contain poorly replicated features, at 439 centennial and shorter scales where radiocarbon uncertainties, sample spacing, and reconstruction error 440 may all be factors. However, by averaging across multiple records in each sub-region, we have reduced 441 the random sources of error and the remaining disparities will require more detailed analyses to 442 diagnose.

$444 \quad 4.2$ Uncertainties and sources of error

445 Some important differences among records probably arose from non-climatic factors. For example, raw 446 (not detrended) alkenone-based SST reconstructions indicate, and may faithfully capture, a substantial 447 background cooling trend of $>5^{\circ} \mathrm{C}$ in the western Atlantic during the Holocene (Sachs, 2007), but our 448 MTWM reconstructions only correlate well with the SST records once the SSTs have been linearly 449 detrended (Fig. 6D). Both the MTWM and SST reconstructions indicate maximum warmth relative to 450 any background trend from ca. 8-5 ka, which is consistent with macrofossil evidence that tree species 451 in the northeastern U.S. grew at higher elevations at the time than today (Jackson and Whitehead, 1991; 452 Shuman et al., 2004; Spear et al., 1994). In contrast, greater than modern temperatures in the raw SST 453 records during the YD, just prior to the start of a large magnitude Holocene cooling trend (Sachs, 454 2007), differ from terrestrial inferences about the YD drawn from pollen, chironomid, lake 455 productivity, and stable isotope data from the Atlantic coast of North America (Hou et al., 2007; 456 Levesque et al., 1997; Peteet et al., 1990). Other paleoceanographic records also do not confirm the 457 magnitude of the subsequent Holocene cooling (Kim et al., 2007, 2004; Solignac et al., 2004;

458 Thornalley et al., 2009). Consequently, a linear or similar trend in the raw SST reconstructions may 459 have been generated by nutrients or other factors (Prahl et al., 2006) or may represent a temperature 460 trend unique to the region of the Labrador Current (Sachs, 2007). Only the superimposed variability 461 correlates with other regional records (Fig. 6D, 8). If the detrended SST signal (Fig. 6D) is the most 
462 climatically meaningful component of the record, then mean Holocene temperature reconstructions that 463 incorporate the raw SST reconstructions (i.e., Marcott et al., 2013) may be artificially too high in the 464 early Holocene (Liu et al., 2014).

466 The different long-term trends in the MTWM and raw SST records do not reflect a lag or similar bias 467 in the pollen data, because such biases would have delayed, dampened, or removed the signal of the 468 abrupt changes and multi-century events (Webb III, 1986), which we have identified as a replicated 469 component of the dataset. The same multi-century events in the pollen-inferred data appear in the SST 470 and lake-level reconstructions (Fig. 8); pollen-inferred precipitation changes from these sites also show 471 a strong coherence with the lake-level reconstructions (Marsicek et al., 2013). Correlations among 472 variables in the modern pollen analog dataset (e.g., MTWM with winter temperatures or annual 473 precipitation; Williams and Shuman, 2008), however, may have produced other erroneous trends in our 474 records, especially if winter temperature or effective moisture signals were erroneously translated to 475 the summer temperature reconstructions (Telford and Birks, 2005; Williams and Shuman, 2008).

\subsection{Insolation and ice sheet effects}

478 As many studies have suggested for the past several decades, the most robust long-term features and 479 abrupt changes in the regional record (Fig. 2) can be directly attributed to the effects of insolation and 480 the Laurentide Ice Sheet (Fig. 5). Long-term temperature trends conform with expectations derived 481 from climate model simulations, which show that the albedo, topography, and freshwater flux changes 482 associated with the remnant Laurentide Ice Sheet could have kept many regions cool in the early 483 Holocene by altering regional energy budgets and synoptic circulation patterns (Alder and Hostetler, 484 2015; Liu et al., 2014; Renssen et al., 2009). As a result, peak Holocene temperatures, particularly 485 during the warmest months, were not achieved in most sub-regions until 7 ka when the thermal effects 486 of summer insolation anomalies dominated (compare Fig. 2A with results from Liu et al., 2014). 
488 Short-lived temperature, moisture, and isotopic events between ca. 9.5 and 8.0 ka (Fig. 4-6) may

489 represent part of the North American expression of hemispheric cool events at ca. 9.3 and 8.2 ka (Alley

490 et al., 1997; Fleitmann et al., 2008; Morrill et al., 2013), which were associated with glacial meltwater

491 floods and routing changes driven by ice sheet dynamics (Barber et al., 1999; Yu et al., 2010). The

492 events appear to be less significant and more spatially variable in North America than coincident

493 climatic step changes (Fig. 4-6), which probably represent the consequences of rapid, non-reversing

494 changes in ice sheet height and extent (Dyke, 2004; Shuman et al., 2002; Williams et al., 2010). Similar

495 step changes have been documented at these times in other regions as well (Adkins et al., 2006), but

496 their importance in North America relative to the cold events conforms with expectations that

497 meltwater-related changes in North Atlantic circulation would have produced events centered

498 downwind of the North Atlantic (LeGrande and Schmidt, 2008; Wagner et al., 2013), while non-

499 reversing changes in the height and area of the ice sheet likely produced climatic changes centered on

500 North America (Alder and Hostetler, 2015; Felzer et al., 1996; Pausata et al., 2011).

501

\section{$502 \quad 4.4$ Additional multi-century variability}

503 The repeated multi-century warm/dry events indicated by SST-, MTWM-, and lake-level records in the

504 east over the past 8 ka also represent a robust aspect of the Holocene record (Fig. 8), but their spatial

505 extent and the character of similar multi-century variability in other regions requires more study.

506 Similar variability appears in other datasets (Fig. 6), but outside of the east, few opportunities currently

507 exist to develop a similar multi-site, multi-parameter evaluation of the signals. One exception is the

508 cold event in the mid-continent (Fig. 7) that coincided with reduced dust deposition in Minnesota at ca.

509 5.6-4.8 ka (Fig. 6B).

510 


\subsection{Changes at ca. 5.5 ka}

512 The most prominent deviations from the long-term temperature and moisture trends since 7 ka took 513 place at 5.6-4.8 ka (Fig. 2). Stepwise transitions at ca. 5.7-5.2 ka, particularly in effective moisture, 514 terminated extensive mid-continent aridity and the "Holocene thermal maximum” across much of our 515 study region (Fig. 6). They, thus, widely reversed the effects produced by the decay of the ice sheet and 516 its meltwater before ca. 7 ka (Fig. 6). Some regions such as Ontario had begun to cool before 5.5 ka 517 (Fig. 6), but even there, the largest changes in the available isotope records (Fig. 3C, 4C) likely indicate 518 important changes in atmospheric circulation at ca. 5.5 ka (Kirby et al., 2002; Yu et al., 1997; Zhao et al., 2010). Many of the hydroclimate changes began synchronously at 5.7 ka (see synchrony analyses by Newby et al., 2014; Shuman et al., 2014).

521

522

Explanations for non-reversing shifts at $5.5 \mathrm{ka}$ include amplification of orbital and greenhouse gas 523 forcing by surface-atmosphere interactions, such as related to vegetation or sea ice changes (Claussen et al., 1999; Crucifix et al., 2002), or intrinsic ocean dynamics, such as driven by salt and heat fluxes in 525 the North Atlantic (Goosse et al., 2002; Jongma et al., 2007; Thornalley et al., 2009). Such mechanisms have been proposed and debated as an explanation for the end of the African Humid Period at ca. 5.5 ka (deMenocal et al., 2000; Kropelin et al., 2008; McGee et al., 2013; Shanahan et al., 2015; Tierney and deMenocal, 2013), but changes at this time extended across the Northern Hemisphere (Magny and Haas, 2004; Magny et al., 2006; Oppo et al., 2003; Shuman, 2012b; Thornalley et al., 2009). Our results confirm their importance for mid-latitude North America.

\subsection{Climates of the Common Era}

533 The past 2000 years (the 'Common Era') represent the period with the highest average effective 534 moisture and coolest summers since the decay of the ice sheet (Fig. 2). The rates of cooling and 535 moistening accelerated by ca. $2.1 \mathrm{ka}$, and the changes have many similarities to those at ca. $5.5 \mathrm{ka}$ (Fig. 
2, 5). Consequently, the conditions of the Common Era were not representative of conditions that had

537 persisted for much of the Holocene, and medieval warmth and drought that punctuated the conditions

538 of the Common Era, especially in portions of the east (Fig. 8), rarely reached the magnitude of earlier

539 events (Figs. 6, 8).

541 The climate changes of the Common Era differed, however, across sub-regions (Fig. 6), and thus

542 further confirm the importance of spatial patterning of Holocene climate variations at centennial to

543 millennial scales. Temperatures from Wyoming to Illinois, like dust accumulation rates in Minnesota,

544 were lower before 1 ka than afterward (Fig. 6A,B). Elsewhere, the lowest temperatures and highest

545 effective moisture levels were achieved after 1 ka and then again after the multi-century phase of high

546 temperatures and drought during medieval times, which appears most prominently in MTWM, SST,

547 and lake-level records from the east (Fig. 8). Although the medieval anomaly appears to have been

548 earlier in the coastal east than elsewhere (Fig. 6A-C), the duration of the event is also short relative to

549 the associated temporal uncertainty and the age differences cannot be verified.

550

\section{5. CONCLUSIONS}

552 The consistent climate signals detected across regions and diverse (sedimentary, geochemical, biotic)

553 paleoenvironmental records (Fig. 2-5) indicate an integrated sequence of slow trends, abrupt shifts and

554 accelerations, and multi-century events during the Holocene climate history of mid-latitude North

555 America. The sequence of events captured by our mean temperature and moisture records (Figs. 2 \&

556 6), rate-of-change analyses (Fig. 3), and principal component analyses (Figs. 4-5) confirms that a series

557 of abrupt shifts and transient fluctuations produced important modifications of orbital and ice sheet

558 driven climate trends from the Rocky Mountains to the North Atlantic. However, the same details do

559 not apply to all locations or records (Fig. 6), and $>30 \%$ of the variance in the data derives from local to

560 sub-regional climate patterns (Table 2). 
562 Within the context of sub-regional variation (Fig. 6), widespread, multi-parameter replication of the 563 structure of the climate history indicates that abrupt events had magnitudes equal to about 25-50\% of

564 the long-term changes. They included both positive and negative interference with the long trends, and 565 despite their modest magnitudes, must have produced significant ecological (vegetation/pollen) and

566 geomorphic (lake/dust) consequences to enable detection by the records examined here. Rapid

567 transitions from ca. 9.3-8.2 ka coincided with the declining influence of the Laurentide Ice Sheet and 568 its meltwater, but additional step changes and acceleration of long-term trends at ca. 5.5 and $2.1 \mathrm{ka}$

569 were equally as important and may have resulted from far-field feedbacks related to Northern

570 Hemisphere cooling. The replicated evidence for multi-century, multivariate climate changes provides

571 a benchmark for comparison with simulations aimed at understanding the full spectrum of climate

572 variations, but more detailed data are required to fully map and understand the structure of these 573 spatially varied changes.

\section{ACKNOWLEDGEMENTS}

576 This project was supported by NSF (BCS-0845129; DEB-1146297) and Wyoming Water Research

577 Program/USGS funding to B.S., as well as a NASA Space Grant Fellowship to J.M.

578 (\#NNX10AO95H). We thank contributors of data to the NOAA Paleoclimate and Neotoma Databases;

579 P. Henne, M. Serravezza and W. Oswald for making data available; two anonymous reviewers, D. R. 580 Foster, and T. Webb III for comments on the manuscript.

581

582 
583

584 585 586 587 588 589 590 591

592 593 594 595 596 597 598 599 600 601 602 603 604 605 606 607

\section{Table 1. Site Table}

"MTWM" refers to mean temperature of the warmest month; "SST" to sea-surface temperatures; “18O" to oxygen isotope records; and " $2 \mathrm{H}$ ” to hydrogen isotope records.

\section{Table 2. Principal Component (PCA) loadings}

Sites are sorted by loadings of the variable-specific PCAs.

\section{Figure Captions}

Figure 1. A map of the North American paleoclimate records used here. Numbers correspond with those in Table 1.

Figure 2. A. Mean (solid black line) and median (dashed black line) of all of the pollen- and alkenoneinferred temperature time series from the region (black circles, Fig. 1). Gray lines shows each of the means from all possible factorial combinations of records. B. Mean (solid black line) and median (dashed black line) of all of the effective moisture (lake level and dust) records, plotted as z-scores. Gray lines show all possible factorial combinations. Vertical dashed lines indicate the timing of maxima in the mean rate of change across all data types (Fig. 3A).

Figure 3. Mean rates of change over 200-yr intervals plotted by data type compared with each other. Panel A represents the mean of all of the time series (B-E) below, which show the mean absolute magnitude of change in the various categories of data. The vertical scale indicates $+1 \mathrm{z}$-score (standard deviation) units above each of the horizontal lines, which mark zero for the time series above. The horizontal dashed line in A marks the threshold for distinguishing major episodes of abrupt change (0.26 sd/200 yrs; $85 \%$ of the rates) at 10.9-10.5, 9.4, 8.3, 5.5, 5.2, 4.7, and 0.9-0.6 ka, which are also 
indicated by vertical dashed lines (as in Fig. 2). Peaks within 300 years of each other are treated as 609 single events.

610

611 Figure 4. First (top) and second (bottom) principal component (PC) scores plotted by time for A) all 612 temperature reconstructions, B) all moisture reconstructions, and C) all isotope records. Thick lines 613 indicate the scores based on PCA of all datasets, and gray lines indicate scores based on 100 iterations 614 of the PCA using bootstrapped subsets of the data. Red lines in C represent a PCA that included two 615 datasets (Fayetteville Green Lake and Bison Lake), which otherwise did not have sufficient duration 616 for inclusion in our analyses. Vertical lines indicate maxima in the absolute magnitude of the rate of 617 change in the component scores for each data type; solid lines indicate rates of $>1.5$ units per 200 618 years, and dashed lines indicate 0.9 units per 200 years.

Figure 5. PC scores plotted by time based on the complete dataset. A) Scores for the first component 621 (PC1) are shown with the June insolation trend for $45^{\circ} \mathrm{N}$ (Berger and Loutre, 1991) in red. B) Scores 622 for the second component (PC2) as well as the residuals of PC1 minus the June insolation trend (gray 623 line) are shown with the area of the Laurentide ice sheet (Dyke, 2004) in blue. C-D) Residual scores for 624 PC1 (top) and PC2 (bottom) after both insolation (PC1 only) and ice area trends (PC1 \& 2) have been 625 removed.

Figure 6. Stacks of temperature (top) and moisture (bottom) records from the A) western, B) westcentral, C) east-central, and D) eastern sub-regions. All temperature records are shown as deviations in degrees $C$ from their most recent value; all moisture records are shown as z-scores (anomalies in standard deviations from their mean). Shading indicates the standard error about the mean for all stacks 631 (except, for simplicity, SSTs shown in red in D); time series from individual sites are shown without 632 uncertainty. Sites names included in each stack are listed. MTWM indicates mean temperature of the 
warmest month; SST indicates detrended sea-surface temperatures.

634

635 Figure 7. Pollen-inferred mean temperatures of the warmest month (as anomalies relative to present)

636 for three sites from the west-central sub-region.

637

638 Figure 8. Trends and multi-century climate variability in the eastern sub-region over the past 8000 639 years. Time series (which are the same as shown in Fig. 6D) represent the means of the available 640 reconstructions of A) sea-surface temperatures (SST), B) mean temperature of the warmest month 641 (MTWM), and C) lake level. The red line in C represents the linear model of the mean lake-level 642 changes based on the mean of the temperature records (both SSTs and MTWM); for comparison, blue 643 shading shows the standard error about the mean lake-level reconstruction. Gray shading indicates 644 multi-century deviations from the long-term temperature trends. Vertical lines indicate the beginning 645 (tan) and end (blue) of multi-century droughts reconstructed in coastal Massachusetts, based on the 646 mode of the age distributions calculated for regional drought events by Newby et al. (2014).

647 
649

650

651

652

653

654

655

656

657

658

659

660

661

662

663

664

665

666

667

668

669

670

671

672

673

674

675

676

677

678

679

680

681

682

683

684

685

686

687

688

689

690

691

692

693

694

695

Alder, J.R., Hostetler, S.W., 2015. Global climate simulations at 3000-year intervals for the last 21000 years with the GENMOM coupled atmosphere-ocean model. Climate of the Past 11, 449-471.

Alley, R.B., 2003. Raising paleoceanography. Paleoceanography 18, 1085. doi:10.1029/2003pa000942

Alley, R.B., Mayewski, P.A., Sowers, T., Stuiver, M., Taylor, K.C., Clark, P.U., 1997. Holocene climatic instability: A prominent, widespread event 8200 yr ago. Geology 25, 483-486. doi:10.1130/0091-7613(1997)025<0483:hciapw>2.3.co;2

Anderson, L., 2012. Rocky Mountain hydroclimate: Holocene variability and the role of insolation, ENSO, and the North American Monsoon. Global and Planetary Change 92-93, 198-208. doi:10.1016/j.gloplacha.2012.05.012

Anderson, L., 2011. Holocene record of precipitation seasonality from lake calcite d18O in the central Rocky Mountains, United States. Geology 39, 211-214. doi:10.1130/g31575.1

Barber, D.C., Dyke, A., Hillaire-Marcel, C., Jennings, A.E., Andrews, J.T., Kerwin, M.W., Bilodeau, G., McNeely, R., Southon, J., Morehead, M.D., Gagnon, J.M., 1999. Forcing of the cold event of 8,200 years ago by catastrophic drainage of Laurentide lakes. Nature 400, 344-348.

Bartlein, P., Harrison, S., Brewer, S., Connor, S., Davis, B., Gajewski, K., Guiot, J., Harrison-Prentice, T., Henderson, A., Peyron, O., Prentice, I., Scholze, M., Seppa, H., Shuman, B., Sugita, S., Thompson, R., Viau, A., Williams, J., Wu, H., 2011. Pollen-based continental climate reconstructions at 6 and 21 ka: a global synthesis. Climate Dynamics 37, 775-802. doi:10.1007/s00382-010-0904-1

Berger, A., Loutre, M.F., 1991. Insolation values for the climate of the last 10 million years. Quaternary Science Reviews 10, 297.

Booth, R.K., Jackson, S.T., Forman, S.L., Kutzbach, J.E., Bettis, E.A., Kreig, J., Wright, D.K., 2005. A severe centennial-scale drought in midcontinental North America 4200 years ago and apparent global linkages. Holocene 15, 321.

Booth, R.K., Notaro, M., Jackson, S.T., Kutzbach, J.E., 2006. Widespread drought episodes in the western Great Lakes region during the past 2000 year: Geological extent and potential mechanisms. Earth and Planetary Science Letters 242, 415-427.

Bright, J., Kaufman, D.S., Forester, R.M., Dean, W.E., 2006. A continuous 250,000-yr record of oxygen and carbon isotopes in ostracode and bulk-sediment carbonate from Bear Lake, UtahIdaho. Quaternary Science Reviews 25, 2258-2270. doi:10.1016/j.quascirev.2005.12.011

Bryson, R.A., 1966. Air masses, streamlines, and the boreal forest. Geological Society of America Bulletin 8, 228.

Claussen, M., Kubatzki, C., Brovkin, V., Ganopolski, A., Hoelzmann, P., Pachur, H.J., 1999. Simulation of an abrupt change in Saharan vegetation in the mid-Holocene. Geophysical Research Letters 26, 2037-2040.

COHMAP, M., 1988. Climate changes of the last 18,000 years: observations and model simulations. Science 241, 1043-1052.

Cook, E.R., Krusic, P.J., 2004. The North American Drought Atlas [WWW Document].

Crucifix, Loutre, Tulkens, Fichefet, Berger, 2002. Climate evolution during the Holocene: a study with an Earth system model of intermediate complexity. Climate Dynamics 19, 43-60. doi:10.1007/s00382-001-0208-6

Dansgaard, W., 1964. Stable isotopes in precipitation. Tellus 16, 436-468. doi:10.1111/j.21533490.1964.tb00181.x

Dean, W.E., 1997. Rates, timing, and cyclicity of Holocene eolian activity in north-central United States; evidence from varved lake sediments. Geology 25, 331-334.

deMenocal, P., Ortiz, J., Guilderson, T., Adkins, J., Sarnthein, M., Baker, L., Yarusinsky, M., 2000. Abrupt onset and termination of the African Humid Period:: rapid climate responses to gradual 
insolation forcing. Quaternary Science Reviews 19, 347-361.

Digerfeldt, G., 1986. Studies on past lake-level fluctuations, in: Berglund, B.E. (Ed.), Handbook of Holocene Palaeoecology and Palaeohydrology. John Wiley and Sons, Chichester, U. K., pp. 127-142.

Donders, T.H., Wagner-Cremer, F., Visscher, H., 2008. Integration of proxy data and model scenarios for the mid-Holocene onset of modern ENSO variability. Quaternary Science Reviews 27, 571579.

Dyke, A.S., 2004. An outline of North American deglaciation with emphasis on central and northern Canada, in: Ehlers, J., Gibbard, P.L. (Eds.), Developments in Quaternary Science. Elsevier, pp. 373-424.

Felzer, B., Oglesby, R.J., Webb, T., Hyman, D.E., 1996. Sensitivity of a general circulation model to changes in northern hemisphere ice sheets. J. Geophys. Res. 101, 19077-19092. doi:10.1029/96JD01219

Fleitmann, D., Mudelsee, M., Burns, S.J., Bradley, R.S., Kramers, J., Matter, A., 2008. Evidence for a widespread climatic anomaly at around 9.2 ka before present. Paleoceanography 23, PA1102. doi:10.1029/2007pa001519

Forman, S.L., Oglesby, R., Webb, R.S., 2001. Temporal and spatial patterns of Holocene dune activity on the Great Plains of North America: megadroughts and climate links. Global and Planetary Change 29, 1-29.

Foster, D.R., Oswald, W.W., Faison, E.K., Doughty, E.D., Hansen, B.C.S., 2006. A climatic driver for abrupt mid-Holocene vegetation dynamics and the hemlock decline in New England. Ecology 87, 2959-2966.

Gibson, J.J., Edwards, T.W.D., 2002. Regional water balance trends and evaporation-transpiration partitioning from a stable isotope survey of lakes in northern Canada. Global Biogeochem. Cycles 16, 1026. doi:10.1029/2001gb001839

Gibson, J.J., Prepas, E.E., McEachern, P., 2002. Quantitative comparison of lake throughflow, residency, and catchment runoff using stable isotopes: modelling and results from a regional survey of Boreal lakes. Journal of Hydrology 262, 128-144.

Goosse, H., Renssen, H., Selten, F.M., Haarsma, R.J., Opsteegh, J.D., 2002. Potential causes of abrupt climate events: A numerical study with a three-dimensional climate model. Geophys. Res. Lett. 29, 1860. doi:10.1029/2002gl014993

Granger, C., 1969. Investigating Causal Relations by Econometric Models and Cross-Spectral Methods. Econometrica 37, 424-438.

Grimm, E.C., Donovan, J.J., Brown, K.J., 2011. A high-resolution record of climate variability and landscape response from Kettle Lake, northern Great Plains, North America. Quaternary Science Reviews 30, 2626-2650.

Halfen, A.F., Johnson, W.C., 2013. A review of Great Plains dune field chronologies. Aeolian Research 10, 135-160. doi:10.1016/j.aeolia.2013.03.001

Haslett, J., Parnell, A., 2008. A simple monotone process with application to radiocarbon-dated depth chronologies. Journal of the Royal Statistical Society: Series C (Applied Statistics) 57, 399418. doi:10.1111/j.1467-9876.2008.00623.x

Henderson, A.K., Shuman, B., 2009. Hydrogen and Oxygen Isotopic Compositions of Lake Water in the Western United States. Bulletin of the Geological Society of America 121, 1179-1189.

Henne, P.D., Hu, F.S., 2010. Holocene climatic change and the development of the lake-effect snowbelt in Michigan, USA. Quaternary Science Reviews 29, 940-951. doi:10.1016/j.quascirev.2009.12.014

Hou, J., Huang, Y., Oswald, W.W., Foster, D.R., Shuman, B., 2007. Centennial-scale compoundspecific hydrogen isotope record of Pleistocene-Holocene climate transition from southern New England. Geophysical Research Letters 34, L19706. doi:10.1029/2007GL030303 
745

746

747

748

749

750

751

752

753

754

755

756

757

758

759

760

761

762

763

764

765

766

767

768

769

770

771

772

773

774

775

776

777

778

779

780

781

782

783

784

785

786

787

788

789

790

791

792

793

Jackson, S.T., Whitehead, D.R., 1991. Holocene Vegetation Patterns in the Adirondack Mountains. Ecology 72, 641-653.

Jasechko, S., Sharp, Z.D., Gibson, J.J., Birks, S.J., Yi, Y., Fawcett, P.J., 2013. Terrestrial water fluxes dominated by transpiration. Nature 496, 347-350. doi:10.1038/nature11983

Jongma, J.I., Prange, M., Renssen, H., Schulz, M., 2007. Amplification of Holocene multicentennial climate forcing by mode transitions in North Atlantic overturning circulation. Geophys. Res. Lett. 34, L15706. doi:10.1029/2007gl030642

Kaufman, D.S., Ager, T.A., Anderson, N.J., Anderson, P.M., Andrews, J.T., Bartlein, P.J., Brubaker, L.B., Coats, L.L., Cwynar, L.C., Duvall, M.L., Dyke, A.S., Edwards, M.E., Eisner, W.R., Gajewski, K., Geirsd $\tilde{A}^{3} t t i r$, A., Hu, F.S., Jennings, A.E., Kaplan, M.R., Kerwin, M.W., Lozhkin, A.V., MacDonald, G.M., Miller, G.H., Mock, C.J., Oswald, W.W., Otto-Bliesner, B.L., Porinchu, D.F., RÃ¹/4hland, K., Smol, J.P., Steig, E.J., Wolfe, B.B., 2004. Holocene thermal maximum in the western Arctic $\left(0-180^{\circ} \mathrm{W}\right)$. Quaternary Science Reviews 23, 529-560. doi:10.1016/j.quascirev.2003.09.007

Kelly, R.L., Surovell, T.A., Shuman, B., Smith, G.M., 2013. A Continuous Climatic Impact on Holocene Human Population in the Rocky Mountains. Proceedings of the National Academy of Science 110, 443-447. doi:10.1073/pnas.1201341110

Kim, J., Meggers, H., Rimbu, N., Lohmann, G., Freudenthal, T., Mueller, P.J., Schneider, R.R., 2007. Impacts of the North Atlantic gyre circulation on Holocene climate off northwest Africa. Geology 35, 387-390. doi:http://dx.doi.org.libproxy.uwyo.edu/10.1605/01.3010001952419.2007

Kim, J.-H., Rimbu, N., Lorenz, S.J., Lohmann, G., Nam, S.-I., Schouten, S., Rühlemann, C., Schneider, R.R., 2004. North Pacific and North Atlantic sea-surface temperature variability during the Holocene. Quaternary Science Reviews 23, 2141-2154.

Kirby, M.E., Mullins, H.T., Patterson, W.P., Burnett, A.W., 2002. Late glacial-Holocene atmospheric circulation and precipitation in the northeast United States inferred from modern calibrated stable oxygen and carbon isotopes. Geological Society of America Bulletin 114, 1326-1340. doi:10.1130/0016-7606(2002)114<1326:lghaca >2.0.co;2

Kohfeld, K.E., Harrison, S.P., 2000. How well can we simulate past climates? Evaluating the models using glabal palaeoenvironmental data sets. Quaternary Science Reviews 19, 321-346.

Kropelin, S., Verschuren, D., Lezine, A.M., Eggermont, H., Cocquyt, C., Francus, P., Cazet, J.P., Fagot, M., Rumes, B., Russell, J.M., Darius, F., Conley, D.J., Schuster, M., von Suchodoletz, H., Engstrom, D.R., 2008. Climate-Driven Ecosystem Succession in the Sahara: The Past 6000 Years. Science 320, 765-768. doi:10.1126/science.1154913

LeGrande, A.N., Schmidt, G.A., 2009. Sources of Holocene variability of oxygen isotopes in paleoclimate archives. Clim. Past 5, 441-455. doi:10.5194/cp-5-441-2009

LeGrande, A.N., Schmidt, G.A., 2008. Ensemble, water isotope enabled, coupled general circulation modeling insights into the 8.2 ka event. Paleoceanography 23, PA3207. doi:10.1029/2008pa001610

Levesque, A.J., Cwynar, L.C., Walker, I.R., 1997. Exceptionally steep north-south gradients in lake temperatures during the last deglaciation. Nature 385, 423-426.

Liu, Z., Bowen, G.J., Welker, J.M., 2010. Atmospheric circulation is reflected in precipitation isotope gradients over the conterminous United States. Journal of Geophysical Research: Atmospheres 115, D22120. doi:10.1029/2010jd014175

Liu, Z., Zhu, J., Rosenthal, Y., Zhang, X., Otto-Bliesner, B.L., Timmermann, A., Smith, R.S., Lohmann, G., Zheng, W., Timm, O.E., 2014. The Holocene temperature conundrum. PNAS 111, E3501E3505. doi:10.1073/pnas.1407229111

Magny, M., Haas, J.N., 2004. A major widespread climatic change around $5300 \mathrm{cal}$. yr BP at the time of the Alpine Iceman. Journal of Quaternary Science 19, 423-430. doi:10.1002/jqs.850 
794

795

796

797

798

799

800

801

802

803

804

805

806

807

808

809

810

811

812

813

814

815

816

817

818

819

820

821

822

823

824

825

826

827

828

829

830

831

832

833

834

835

836

837

838

839

840

841

842

Magny, M., Leuzinger, U., Bortenschlager, S., Haas, J.N., 2006. Tripartite climate reversal in Central Europe 5600-5300 years ago. Quaternary Research 65, 3-19.

Mann, M.E., Zhang, Z., Rutherford, S., Bradley, R.S., Hughes, M.K., Shindell, D., Ammann, C., Faluvegi, G., Ni, F., 2009. Global Signatures and Dynamical Origins of the Little Ice Age and Medieval Climate Anomaly. Science 326, 1256-1260. doi:10.1126/science.1177303

Marcott, S.A., Shakun, J.D., Clark, P.U., Mix, A.C., 2013. A Reconstruction of Regional and Global Temperature for the Past 11,300 Years. Science 339, 1198-1201. doi:10.1126/science.1228026

Marsicek, J.P., Shuman, B., Brewer, S., Foster, D.R., Oswald, W.W., 2013. Moisture and temperature changes associated with the mid-Holocene Tsuga decline in the northeastern United States. Quaternary Science Reviews 80, 129-142. doi:10.1016/j.quascirev.2013.09.001

Martin-Puertas, C., Matthes, K., Brauer, A., Muscheler, R., Hansen, F., Petrick, C., Aldahan, A., Possnert, G., van Geel, B., 2012. Regional atmospheric circulation shifts induced by a grand solar minimum. Nature Geosci 5, 397-401. doi:10.1038/ngeo1460

Mason, J.A., Jacobs, P.M., Hanson, P.R., Miao, X.M., Goble, R.J., 2003. Sources and paleoclimatic significance of Holocene Bignell Loess, central Great Plains, USA. Quaternary Research 60, 330.

Mayewski, P.A., Rohling, E., Stager, C., Karlen, K., Maasch, K., Meeker, L.D., Meyerson, E., Gasse, F., van Kreveld, S., Holmgren, K., Lee-Thorp, J., Rosqvist, G., Rack, F., Staubwasser, M., Shneider, R., 2004. Holocene climate variability. Quaternary Research 62, 243.

McGee, D., deMenocal, P.B., Winckler, G., Stuut, J.B.W., Bradtmiller, L.I., 2013. The magnitude, timing and abruptness of changes in North African dust deposition over the last 20,000 yr. Earth and Planetary Science Letters 371-372, 163-176. doi:10.1016/j.epsl.2013.03.054

McKean, R.L.S., Goble, R.J., Mason, J.B., Swinehart, J.B., Loope, D.B., 2015. Temporal and spatial variability in dune reactivation across the Nebraska Sand Hills, USA. The Holocene 25, 523535. doi:10.1177/0959683614561889

Morrill, C., Anderson, D.M., Bauer, B.A., Buckner, R., Gille, E.P., Gross, W.S., Hartman, M., Shah, A., 2013. Proxy benchmarks for intercomparison of 8.2 ka simulations. Clim. Past 9, 423-432. doi:10.5194/cp-9-423-2013

Mott, R.J., Grant, D.R., Stea, R., Occhietti, S., 1986. Late-glacial climatic oscillation in Atlantic Canada equivalent to the Allerod YOUNGER DRYAS EVENT. Nature 323, 247-250.

Muhs, D.R., Bettis, E.A., Aleinikoff, J.N., McGeehin, J.P., Beann, J., Skipp, G., Marshall, B.D., Roberts, H.M., Johnson, W.C., Benton, R., 2008. Origin and paleoclimatic significance of late Quaternary loess in Nebraska: Evidence from stratigraphy, chronology, sedimentology, and geochemistry. Geological Society of America Bulletin 120, 1378-1407. doi:10.1130/B26221.1

Munoz, S.E., Gajewski, K., Peros, M.C., 2011. Synchronous environmental and cultural change in the prehistory of the northeastern United States. Proceedings of the National Academy of Science 107, 22008-2201.

NCDC, 1994. Time Bias Corrected Divisional Temperature-Precipitation-Drought Index. Documentation for dataset TD-9640. DBMB, NCDC, NOAA, Federal Building, 37 Battery Park Ave. Asheville, NC 28801-2733, Asheville, NC 28801-2733.

Neff, U., Burns, S.J., Mangini, A., Mudelsee, M., Fleitmann, D., Matter, A., 2001. Strong coherence between solar variability and the monsoon in Oman between 9 and 6kyr ago. Nature 411, 290.

Nelson, D.B., Abbott, M.B., Steinman, B., Polissar, P.J., Stansell, N.D., Ortiz, J.D., Rosenmeier, M.F., Finney, B.P., Riedel, J., 2011. Drought variability in the Pacific Northwest from a 6,000-yr lake sediment record. Proceedings of the National Academy of Sciences 108, 3870-3875. doi:10.1073/pnas.1009194108

Nelson, D.M., Hu, F.S., 2008. Patterns and drivers of Holocene vegetational change near the prairieforest ecotone in Minnesota: revisiting McAndrews' transect. New Phytologist 179, 449-459.

Newby, P., Shuman, B., Donnelly, J.P., Karnauskas, K.B., Marsicek, J.P., 2014. Centennial-to- 
843

844

845

846

847

848

849

850

851

852

853

854

855

856

857

858

859

860

861

862

863

864

865

866

867

868

869

870

871

872

873

874

875

876

877

878

879

880

881

882

883

884

885

886

887

888

889

890

891

Millennial Hydrologic Trends and Variability along the North Atlantic Coast, U.S.A., during the Holocene. Geophys. Res. Lett. 41. doi:10.1002/2014GL060183

Nichols, J.E., Huang, Y., 2012. Hydroclimate of the northeastern United States is highly sensitive to solar forcing. Geophys. Res. Lett. 39, L04707. doi:10.1029/2011GL050720

Oppo, D.W., McManus, J.F., Cullen, J.L., 2003. Palaeo-oceanography: Deepwater variability in the Holocene epoch. Nature 422, 277-277.

Overpeck, J.T., Webb III, T., Prentice, I.C., 1985. Quantitative interpretation of fossil pollen spectra: dissimilarity coefficients and the method of modern analogs. Quaternary Research 23, 87-108.

Parnell, A.C., Haslett, J., Allen, J.R.M., Buck, C.E., Huntley, B., 2008. A flexible approach to assessing synchroneity of past events using Bayesian reconstructions of sedimentation history. Quaternary Science Reviews 27, 1872-1885. doi:10.1016/j.quascirev.2008.07.009

Pausata, F.S.R., Li, C., Wettstein, J.J., Kageyama, M., Nisancioglu, K.H., 2011. The key role of topography in altering North Atlantic atmospheric circulation during the last glacial period.

Clim. Past 7, 1089-1101. doi:10.5194/cp-7-1089-2011

Peteet, D.M., Vogel, J.S., Nelson, D.E., Southron, J.R., Nickmann, R.J., Heusser, L.E., 1990. Younger Dryas climatic reversal in northeastern USA? AMS ages for an older problem. Quaternary Research 33, 219.

Prahl, F.G., Mix, A.C., Sparrow, M.A., 2006. Alkenone paleothermometry: Biological lessons from marine sediment records off western South America. Geochimica et Cosmochimica Acta 70, 101-117. doi:10.1016/j.gca.2005.08.023

Pribyl, P., Shuman, B.N., 2014. A computational approach to Quaternary lake-level reconstruction applied in the central Rocky Mountains, Wyoming, USA. Quaternary Research 82, 249-259. doi:10.1016/j.yqres.2014.01.012

R Core Development Team, 2009. R: A language and environment for statistical computing. R Foundation for Statistical Computing, Vienna, Austria.

Rach, O., Brauer, A., Wilkes, H., Sachse, D., 2014. Delayed hydrological response to Greenland cooling at the onset of the Younger Dryas in western Europe. Nature Geosci 7, 109-112. doi:10.1038/ngeo2053

Renssen, H., Seppa, H., Heiri, O., Roche, D.M., Goosse, H., Fichefet, T., 2009. The spatial and temporal complexity of the Holocene thermal maximum. Nature Geosci 2, 411-414.

Sachs, J.P., 2007. Cooling of Northwest Atlantic slope waters during the Holocene. Geophys. Res. Lett. 34, L03609. doi:10.1029/2006gl028495

Schlaepfer, D.R., Ewers, B.E., Shuman, B.N., Williams, D.G., Frank, J.M., Massman, W.J., Lauenroth, W.K., 2014. Terrestrial water fluxes dominated by transpiration: Comment. Ecosphere 5, art61. doi:10.1890/ES13-00391.1

Shanahan, T.M., McKay, N.P., Hughen, K.A., Overpeck, J.T., Otto-Bliesner, B., Heil, C.W., King, J., Scholz, C.A., Peck, J., 2015. The time-transgressive termination of the African Humid Period.

Nature Geosci 8, 140-144. doi:10.1038/ngeo2329

Shuman, B., 2012a. Recent Wyoming temperature trends, their drivers, and impacts in a 14,000-year context. Climatic Change 112, 429-447. doi:10.1007/s10584-011-0223-5

Shuman, B., 2012b. Patterns, processes, and impacts of abrupt climate change in a warm world: the past 11,700 years. Wiley Interdisciplinary Reviews: Climate Change 3, 19-43.

doi:10.1002/wcc.152

Shuman, B., Huang, Y., Newby, P., Wang, Y., 2006. Compound-Specific Isotopic Analyses Track Changes in the Seasonality of Precipitation in the Northeastern United States at ca. 8200 cal yr BP. Quaternary Science Reviews 25, 2992-3002.

Shuman, B., Pribyl, P., Minckley, T.A., Shinker, J.J., 2010. Rapid hydrologic shifts and prolonged droughts in Rocky Mountain headwaters during the Holocene. Geophys. Res. Lett. 37, L06701. doi:10.1029/2009gl042196 
892

893

894

895

896

897

898

899

900

901

902

903

904

905

906

907

908

909

910

911

912

913

914

915

916

917

918

919

920

921

922

923

924

925

926

927

928

929

930

931

932

933

934

935

936

937

938

939

940
Shuman, B.N., Bartlein, P.J., Logar, N., Newby, P., Webb, T., 2002. Parallel climate and vegetation responses to the early Holocene collapse of the Laurentide Ice Sheet. Quaternary Science Reviews 21, 1793-1805.

Shuman, B.N., Carter, G.E., Hougardy, D.D., Powers, K., Shinker, J.J., 2014. A north-south moisture dipole at multi-century scales in the Central and Southern Rocky Mountains, U.S.A., during the late Holocene. Rocky Mountain Geology 49, 33-49. doi:10.2113/gsrocky.49.1.33

Shuman, B.N., Newby, P., Huang, Y., Webb, T., 2004. Evidence for the close climatic control of New England vegetation history. Ecology 85, 1297-1310.

Smith, A.J., Donovan, J.J., Ito, E., Engstrom, D.R., Panek, V.A., 2002. Climate-driven hydrologic transients in lake sediment records: multoproxy record of mid-Holocene drought. Quaternary Science Reviews 21, 625.

Smith, M.A., Hollander, D.J., 1999. Historical linkage between atmospheric circulation patterns and the oxygen isotopic record of sedimentary carbonates from Lake Mendota, Wisconsin, USA. Geology 27, 589-592. doi:10.1130/0091-7613(1999)027<0589:hlbacp>2.3.co;2

Solignac, S., de Vernal, A., Hillaire-Marcel, C., 2004. Holocene sea-surface conditions in the North Atlantic--contrasted trends and regimes in the western and eastern sectors (Labrador Sea vs. Iceland Basin). Quaternary Science Reviews 23, 319-334.

Spear, R.W., Davis, M.B., Shane, L.C.K., 1994. Lake Quaternary history of low-and mid-elevation vegetation in the White Mountains of New Hampshire. Ecological Monographs 64, 85.

Steinman, B.A., Abbott, M.B., 2013. Isotopic and hydrologic responses of small, closed lakes to climate variability: Hydroclimate reconstructions from lake sediment oxygen isotope records and mass balance models. Geochimica et Cosmochimica Acta 105, 342-359. doi:10.1016/j.gca.2012.11.027

Telford, R.J., Birks, H.J.B., 2005. The secret assumption of transfer functions: problems with spatial autocorrelation in evaluating model performance. Quaternary Science Reviews 24, 2173-2179. doi:10.1016/j.quascirev.2005.05.001

Thornalley, D.J.R., Elderfield, H., McCave, I.N., 2009. Holocene oscillations in temperature and salinity of the surface subpolar North Atlantic. Nature 457, 711-714.

Tierney, J.E., deMenocal, P.B., 2013. Abrupt Shifts in Horn of Africa Hydroclimate Since the Last Glacial Maximum. Science 342, 843-846. doi:10.1126/science.1240411

Van Geel, B., Heusser, C.J., Renssen, H., Schuurmans, C.J.E., 2000. Climatic change in Chile at around 2700 BP and global evidence for solar forcing: a hypothesis. The Holocene 10, 659-664. doi:10.1191/09596830094908

Viau, A.E., Gajewski, K., Sawada, M.C., Fines, P., 2006. Millennial-scale temperature variations in North America during the Holocene. J. Geophys. Res. 111.

Wagner, A.J., Morrill, C., Otto-Bliesner, B.L., Rosenbloom, N., Watkins, K.R., 2013. Model support for forcing of the 8.2 ka event by meltwater from the Hudson Bay ice dome. Clim Dyn 41, 28552873. doi:10.1007/s00382-013-1706-z

Walker, M.J.C., Berkelhammer, M., Björck, S., Cwynar, L.C., Fisher, D.A., Long, A.J., Lowe, J.J., Newnham, R.M., Rasmussen, S.O., Weiss, H., 2012. Formal subdivision of the Holocene Series/Epoch: a Discussion Paper by a Working Group of INTIMATE (Integration of ice-core, marine and terrestrial records) and the Subcommission on Quaternary Stratigraphy (International Commission on Stratigraphy). J. Quaternary Sci. 27, 649-659. doi:10.1002/jqs.2565

Wanner, H., Beer, J., Bütikofer, J., Crowley, T.J., Cubasch, U., Flückiger, J., Goosse, H., Grosjean, M., Joos, F., Kaplan, J.O., Küttel, M., Müller, S.A., Prentice, I.C., Solomina, O., Stocker, T.F., Tarasov, P., Wagner, M., Widmann, M., 2008. Mid- to Late Holocene climate change: an overview. Quaternary Science Reviews 27, 1791-1828.

Wanner, H., Solomina, O., Grosjean, M., Ritz, S.P., Jetel, M., 2011. Structure and origin of Holocene 
951

952

953

954

955

956

957

958

959

960

961

962

963

964 cold events. Quaternary Science Reviews 30, 3109-3123. doi:10.1016/j.quascirev.2011.07.010 Webb III, T., 1986. Is vegetation in equilibrium with climate? How to interpret late-Quaternary pollen data. Vegetatio 67, 75-91.

Whitmore, J., Gajewski, K., Sawada, M., Williams, J., Shuman, B., Bartlein, P.J., Shafer, S., Minckley, T., Viau, A., Brubaker, L., 2005. An updated modern pollen-climate-vegetation dataset for North America. Quaternary Science Reviews 24, 1828-1848.

Williams, J.W., Shuman, B., 2008. Obtaining accurate and precise environmental reconstructions from the modern analog technique and North American surface pollen dataset. Quaternary Science Reviews 27, 669-687.

Williams, J.W., Shuman, B., Bartlein, P.J., Diffenbaugh, N.S., Webb, T., 2010. Rapid, timetransgressive, and variable responses to early Holocene midcontinental drying in North America. Geology 38, 135-138. doi:10.1130/g30413.1

Yu, S.-Y., Colman, S.M., Lowell, T.V., Milne, G.A., Fisher, T.G., Breckenridge, A., Boyd, M., Teller, J.T., 2010. Freshwater Outburst from Lake Superior as a Trigger for the Cold Event 9300 Years Ago. Science 328, 1262-1266. doi:10.1126/science.1187860

Yu, Z., Andrews, J.H., Eicher, U., 1997. Middle Holocene dry climate caused by change in atmospheric circulation patterns: Evidence from lake levels and stable isotopes. Geology 25, 251-254.

Zhao, Y., Yu, Z.C., Zhao, C., 2010. Hemlock (Tsuga canadensis) declines at 9800 and $5300 \mathrm{cal}$ yr BP caused by Holocene climatic shifts in northeastern North America. The Holocene 20, 877-886. doi:10.1177/0959683610365932 
Table 1

\begin{tabular}{|c|c|c|c|c|c|c|c|c|c|c|c|}
\hline Number Site & State/Province & Latitude & Longitude & 14C dates & Samples & Temperature & Lake Level & Isotope & Dust & Pollen citation & Citation for reconstruction \\
\hline $\begin{array}{ll}1 \text { Rainbow Lake } \\
\end{array}$ & WY & 444.94 & $\begin{array}{l}-109.50 \\
\end{array}$ & 29 & 2220 & & $\mathrm{x}$ & & & & $\begin{array}{l}\text { Shuman and Serravezza, unpub. } \\
\text {. }\end{array}$ \\
\hline 2 Lower Paintrock Lake & wr & 44.39 & -107.38 & 39 & 220 & & $x$ & & & & Serravezza (2016) \\
\hline 3 Lake of the Woods & wy & 43.48 & -109.89 & 21 & 220 & & $\mathrm{x}$ & & & & Pribyl and Shuman (2014) \\
\hline 4 Little Windy Hill Pond & wy & 41.43 & -106.33 & 18 & 220 & & $x$ & & & & Minckley et al. (2012) \\
\hline 5 Upper Big Creek Lake & $\mathrm{CO}$ & 40.91 & -106.62 & 7 & 220 & & $\mathrm{x}$ & & & & Shuman and Pribyl (2015) \\
\hline 6 Emerald Lake & CO & 39.15 & -106.41 & 29 & 220 & & $\mathrm{x}$ & & & & Shuman et al. (2014) \\
\hline 7 Davis Pond & MA & 42.14 & -73.41 & 31 & 220 & & $\mathrm{x}$ & & & & Newby et al. $(2011 ; 2014)$ \\
\hline 8 New Long Pond & MA & 41.85 & -70.68 & 52 & 220 & & $\mathrm{x}$ & & & & Newby et al. $(2009 ; 2014)$ \\
\hline 9, 27 Deep Pond & MA & 41.56 & -70.64 & 53 & $125 / 220$ & MTWM & $\mathrm{x}$ & & & Foster et al. (2006) & Marsicek et al. (2013) \\
\hline 10a Buckbean Bog & wy & 44.30 & -110.26 & 4 & 45 & MTWM & & & & Baker (1976) & Shuman (2012) \\
\hline 10b Sherd Lake & wr & 44.27 & -107.01 & 2 & 48 & MTWM & & & & Burkart (1976) & Shuman (2012) \\
\hline 11 Rice Lake & ND & 48.01 & -101.53 & 14 & 81 & MTWM & & & & Grimm (2001) & This study \\
\hline 12 Moon Lake & ND & 46.86 & -98.16 & 14 & 144 & MTWM & & & & Laird et al. (1996) & This study \\
\hline 13 Pickerel Lake & SD & 45.50 & -97.33 & 3 & 73 & MTWM & & & & Watts and Bright (1968) & This study \\
\hline 14, 32 Steel Lake & $\mathrm{MN}$ & 46.97 & -94.68 & 35 & 119 & MTWM & & & $x$ & Wright et al. (2004) & This study \\
\hline 15 Sharkey Lake & $\mathrm{MN}$ & 44.59 & -93.41 & 9 & 163 & MTWM & & & & Camill et al. (2003) & This study \\
\hline 16 Lake West Okoboji & IA & 43.33 & -95.20 & 9 & 93 & MTWM & & & & Van Zant (1979) & This study \\
\hline 17 Devils Lake & WI & 43.42 & -89.73 & 12 & 98 & MTWM & & & & Maher (1982) & This study \\
\hline 18 Chatsworth Bog & $\mathrm{IL}$ & 40.68 & -88.34 & 9 & 55 & MTWM & & & & King (1981) & This study \\
\hline 19 Nutt Lake & ON & 45.22 & -79.45 & 10 & 83 & MTWM & & & & Bennett (1987) & This study \\
\hline 20 Hams Lake & ON & 43.24 & -80.41 & 10 & 80 & MTWM & & & & Bennett (1987) & This study \\
\hline 21 Graham Lake & ON & 45.18 & -77.35 & 6 & 207 & MTWM & & & & Fuller (1997) & This study \\
\hline 22 High Lake & ON & 44.52 & -76.60 & 8 & 189 & MTWM & & & & Fuller (1997) & This study \\
\hline 23 Spruce Pond & NY & 41.24 & -74.20 & 9 & 141 & MTWM & & & & Maenza-Gmelch (1997) & This study \\
\hline 24 Sutherland Pond & NY & 41.39 & -74.20 & 11 & 140 & MTWM & & & & Maenza-Gmelch (1997) & This study \\
\hline 25 Little Pond-Royalston & MA & 42.68 & -72.19 & 7 & 83 & MTWM & & & & Oswald et al. (2007) & Marsicek et al. (2013) \\
\hline 26 Blood Pond & MA & 42.08 & -71.96 & 15 & 125 & MTWM & & & & Oswald et al. (2007) & Marsicek et al. (2013) \\
\hline 28 Mansell Pond & ME & 45.04 & -68.73 & 10 & 110 & MTWM & & & & Almquist-Jacobson and Sanger (1995) & This study \\
\hline 29 OCE326-GGC30 & (Nova Scotia) & 44.00 & -63.00 & 8 & 141 & SST & & & & & Sachs (2007) \\
\hline 30 CH0798-GGC19 & (Virginia) & 36.87 & -74.57 & 5 & 165 & SST & & & & & Sachs (2007) \\
\hline 31 Elk Lake & $\mathrm{MN}$ & 45.87 & -95.80 & Varves & 162 & & & & $\mathrm{x}$ & & Dean (1997) \\
\hline 33 Bear Lake (cores 96-1/96-2) & UT/ID & 41.98 & -111.33 & 34 & 157 & & & 180 & & & Bright et al. (2006) \\
\hline 34 Bison Lake & co & 39.77 & -107.35 & 9 & 284 & & & 180 & & & Anderson (2011) \\
\hline 35 O'Brien Lake & $\mathrm{MI}$ & 44.64 & -83.88 & 16 & 66 & & & 180 & & & Henne and $\mathrm{Hu}(2010)$ \\
\hline 36 Crawford Pond & ON & 43.47 & -79.95 & 4 & 73 & & & 180 & & & Yu et al. (1997) \\
\hline 37 Fayetteville Green Lake & NY & 43.03 & -75.97 & 6 & 998 & & & 180 & & & Kirby et al. (2003) \\
\hline 38 Grinnell Pond & NJ & 41.10 & -74.63 & 7 & 334 & & & 180 & & & Zhoo et al. (2010) \\
\hline 39 Berry Pond & MA & 42.51 & -73.32 & 16 & 35 & & & $2 \mathrm{H}$ & & & Shuman et al. (2006) \\
\hline
\end{tabular}




\begin{tabular}{|c|c|c|c|c|c|c|c|c|c|c|}
\hline \multirow{3}{*}{$\begin{array}{r}\text { Component: } \\
\text { Percent of Variance: }\end{array}$} & & & \multicolumn{2}{|c|}{ All } & \multicolumn{2}{|c|}{ Temperature } & \multicolumn{2}{|c|}{ Moisture } & \multicolumn{2}{|c|}{ Isotopes } \\
\hline & & & 1 & 2 & 1 & 2 & 1 & 2 & 1 & 2 \\
\hline & & & 34.92 & 21.07 & 35.23 & 28.54 & 51.10 & 19.34 & 42.30 & 23.63 \\
\hline Buckbean Fen/Sherd Lake & WY & $T$ & 0.25 & -0.07 & 0.61 & -0.23 & & & & \\
\hline GGC30 (Nova Scotia) & & SST & 0.24 & 0.01 & 0.39 & -0.04 & & & & \\
\hline Mansell Pond & ME & $T$ & 0.22 & 0.01 & 0.26 & 0.04 & & & & \\
\hline Steel Lake & $\mathrm{MN}$ & $\mathrm{T}$ & 0.06 & 0.32 & 0.22 & 0.70 & & & & \\
\hline Nutt Lake & ON & $\mathrm{T}$ & 0.23 & -0.03 & 0.19 & -0.04 & & & & \\
\hline Blood Pond & MA & $\mathrm{T}$ & 0.10 & 0.17 & 0.15 & 0.25 & & & & \\
\hline High Lake & ON & $\mathrm{T}$ & 0.16 & 0.19 & 0.12 & 0.12 & & & & \\
\hline Little Pond & MA & $\mathrm{T}$ & 0.14 & -0.14 & 0.12 & -0.07 & & & & \\
\hline Graham Lake & ON & $\mathrm{T}$ & 0.13 & 0.17 & 0.11 & 0.10 & & & & \\
\hline Sutherland Pond & NY & $\mathrm{T}$ & 0.19 & 0.13 & 0.11 & 0.06 & & & & \\
\hline Devils Lake & WI & $\mathrm{T}$ & 0.15 & 0.21 & 0.09 & 0.09 & & & & \\
\hline Moon Lake & ND & $\mathrm{T}$ & 0.16 & 0.02 & 0.08 & 0.02 & & & & \\
\hline GGC19 (Virginia) & & SST & 0.05 & 0.26 & 0.06 & 0.25 & & & & \\
\hline Spruce Pond & NY & $T$ & 0.07 & 0.30 & 0.06 & 0.20 & & & & \\
\hline Sharkey Lake & $\mathrm{MN}$ & $\mathrm{T}$ & 0.07 & 0.25 & 0.04 & 0.18 & & & & \\
\hline Rice Lake & ND & $\mathrm{T}$ & 0.05 & 0.03 & 0.03 & 0.01 & & & & \\
\hline Hams Lake & ON & $\mathrm{T}$ & -0.03 & 0.16 & -0.01 & 0.17 & & & & \\
\hline Deep Pond & MA & $\mathrm{T}$ & -0.06 & 0.20 & -0.07 & 0.21 & & & & \\
\hline Pickerel Lake & SD & $\mathrm{T}$ & -0.20 & 0.05 & -0.18 & 0.05 & & & & \\
\hline Lake West Okoboji & IA & $\mathrm{T}$ & -0.10 & -0.05 & -0.20 & -0.19 & & & & \\
\hline Chatsworth Bog & IL & $\mathrm{T}$ & -0.16 & 0.12 & -0.38 & 0.31 & & & & \\
\hline Upper Big Creek Lake & $\mathrm{CO}$ & LL & -0.05 & 0.13 & & & -0.03 & 0.10 & & \\
\hline Little Windy Hill Pond & WY & LL & 0.09 & 0.14 & & & 0.18 & 0.24 & & \\
\hline Lower Paintrock Lake & WY & LL & 0.04 & -0.22 & & & 0.19 & -0.46 & & \\
\hline Steel Lake & $\mathrm{MN}$ & D & 0.23 & 0.15 & & & 0.23 & 0.50 & & \\
\hline Elk Lake & $\mathrm{MN}$ & D & 0.22 & 0.10 & & & 0.28 & 0.39 & & \\
\hline New Long Pond & MA & LL & 0.10 & -0.30 & & & 0.30 & -0.40 & & \\
\hline Lake of the Woods & WY & LL & 0.21 & 0.03 & & & 0.31 & 0.18 & & \\
\hline Davis Pond & MA & LL & 0.19 & -0.23 & & & 0.38 & -0.23 & & \\
\hline Rainbow Lake & WY & LL & 0.25 & -0.05 & & & 0.38 & 0.16 & & \\
\hline Deep Pond & MA & LL & 0.20 & -0.23 & & & 0.39 & -0.21 & & \\
\hline Emerald Lake & $\mathrm{CO}$ & LL & 0.25 & -0.13 & & & 0.42 & -0.01 & & \\
\hline Bear Lake & ID/UT & 180 & -0.16 & 0.08 & & & & & -0.42 & 0.32 \\
\hline Berry Pond & MA & $2 \mathrm{H}$ & 0.05 & 0.07 & & & & & 0.12 & 0.80 \\
\hline O'Brien Lake & MI & 180 & 0.20 & 0.19 & & & & & 0.40 & 0.47 \\
\hline Grinnell Lake & NJ & 180 & 0.19 & -0.05 & & & & & 0.56 & -0.19 \\
\hline Crawford Pond & ON & 180 & 0.22 & -0.17 & & & & & 0.57 & -0.07 \\
\hline
\end{tabular}




\section{Temperature, Lake Level, Dust, and Isotope Records}

- Lake level (1-9) •Temperature (10-30) aDust (31-32) ㅁ Isotope (33-39)

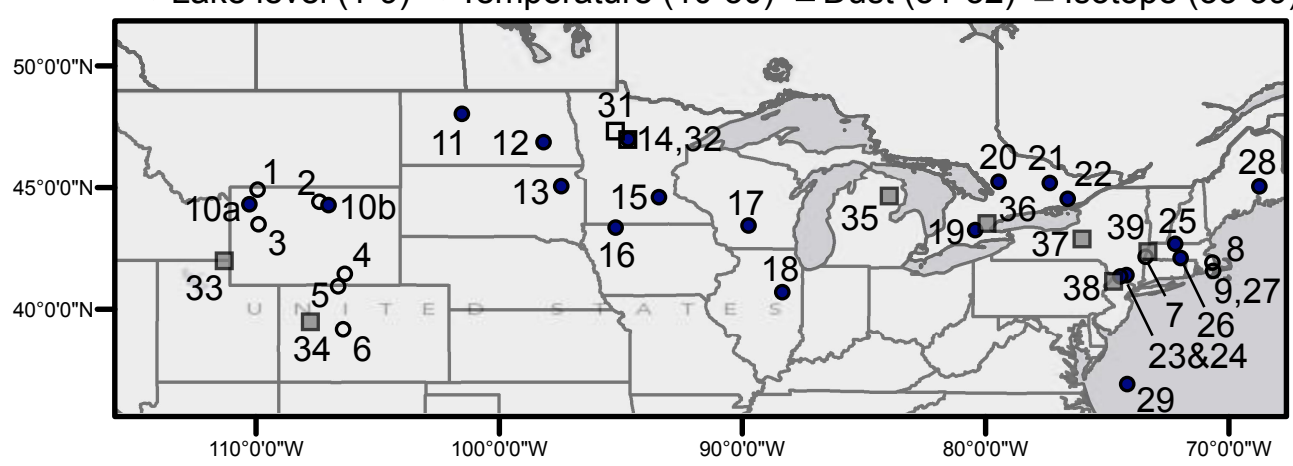




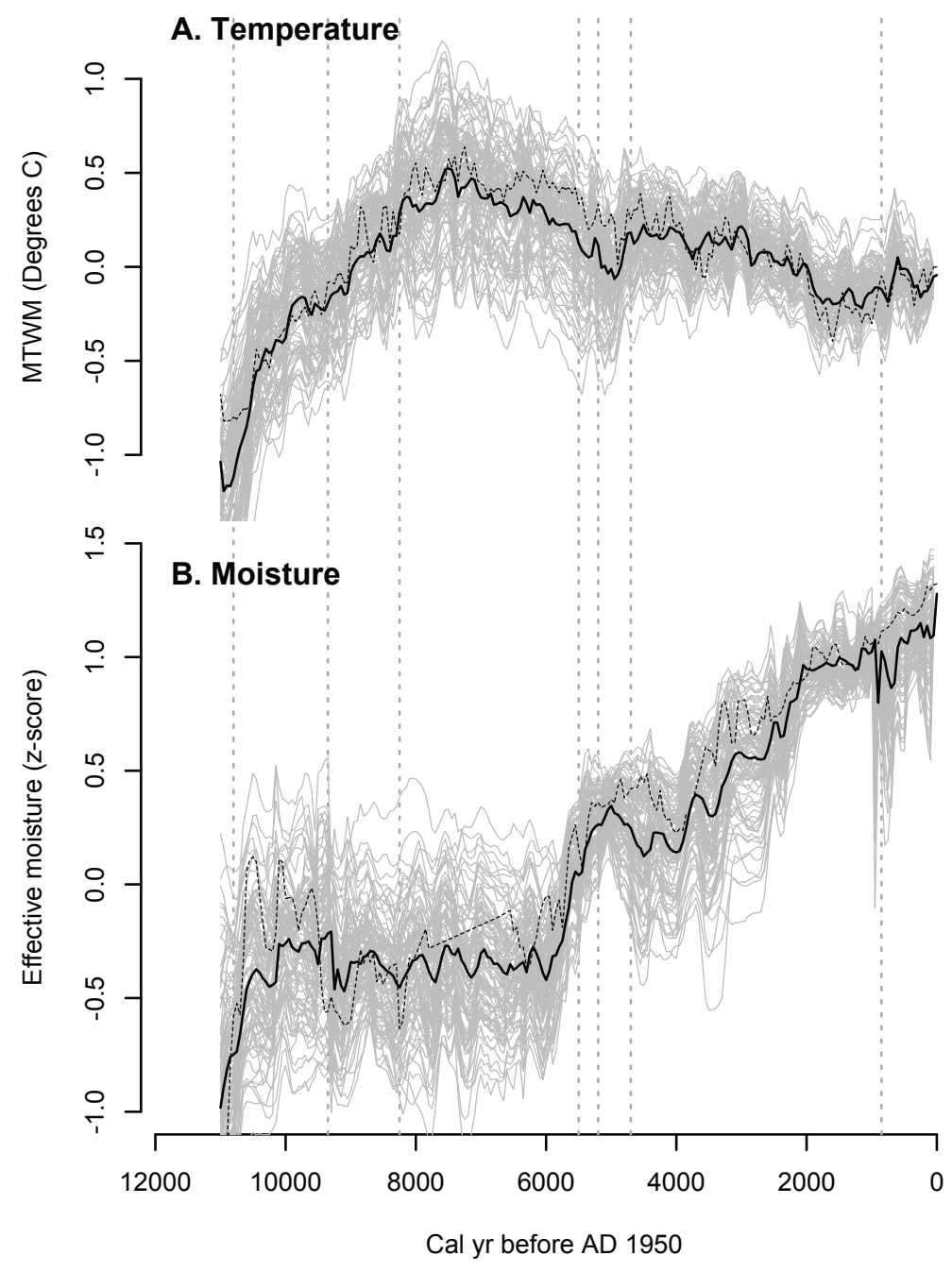

Shuman and Marsicek - Figure 2 


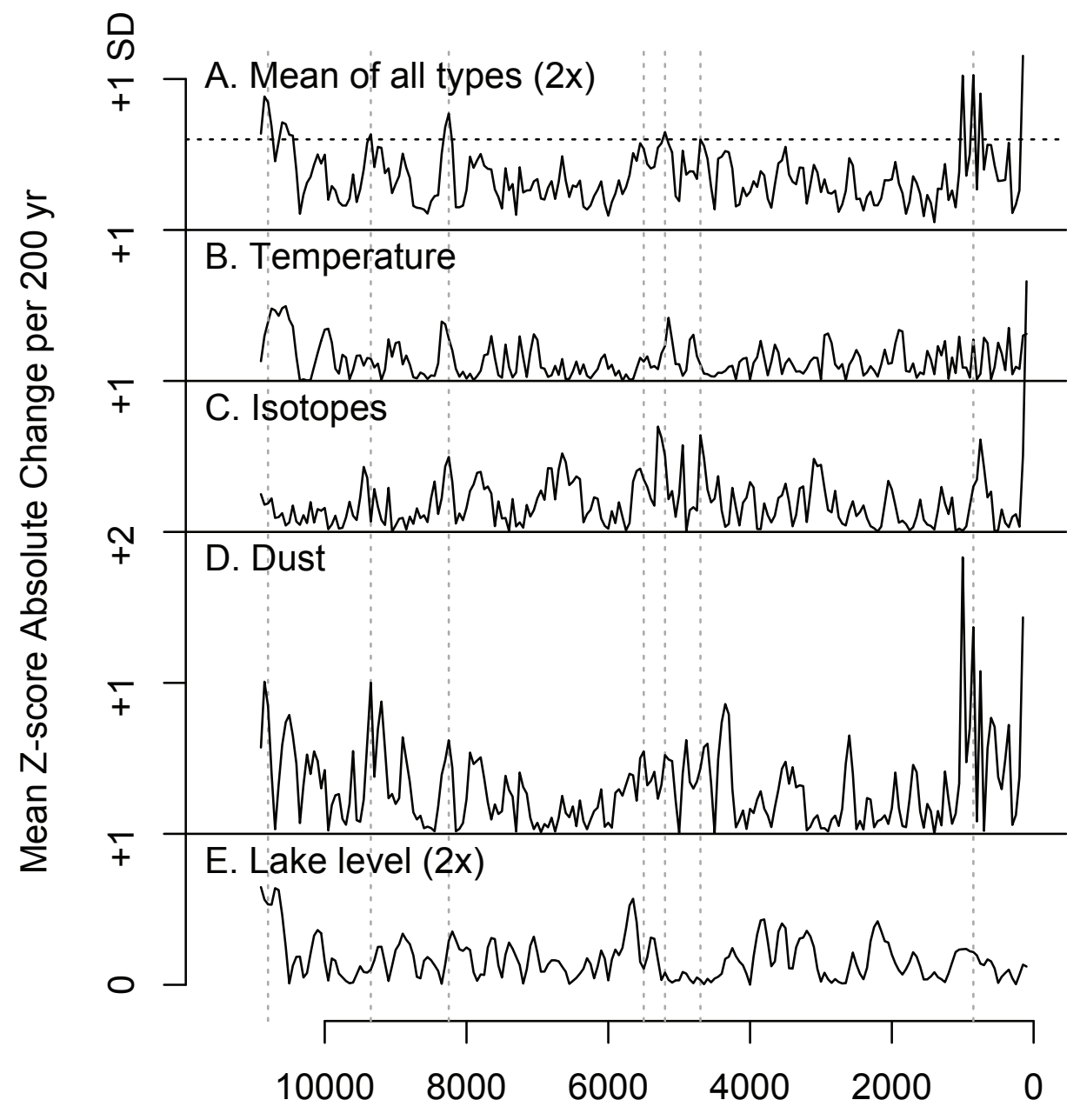

Cal yr before AD 1950 


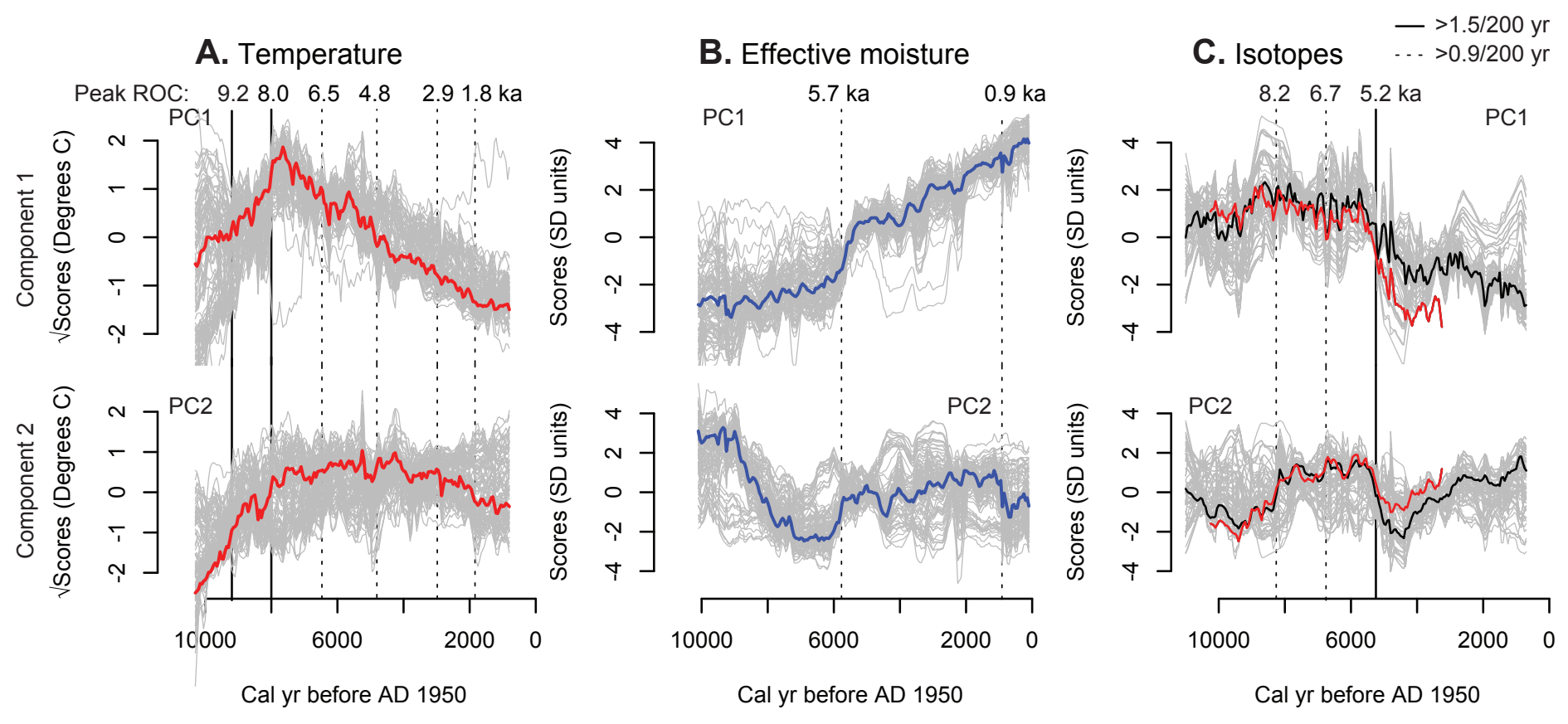


A. Insolation \& PC1

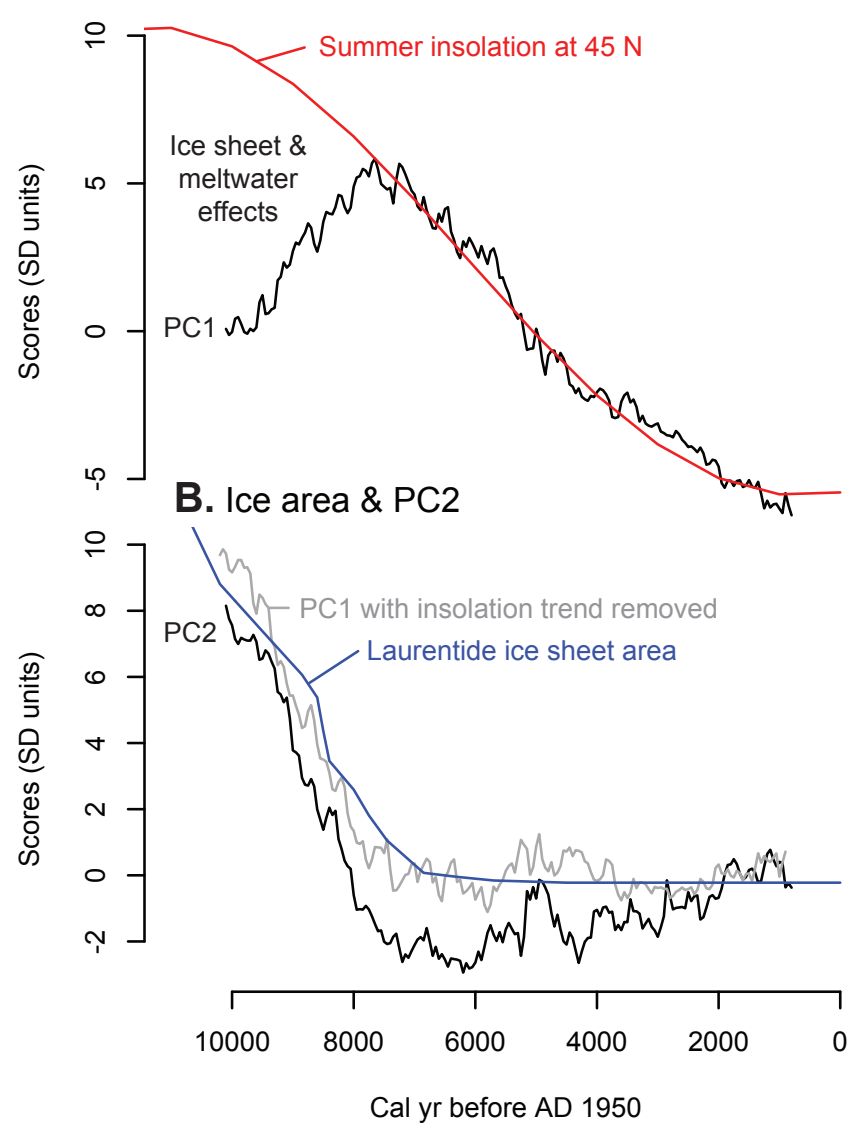

C. PC1 residuals

Changes of $>0.5$ SD in both PC $1 \& 2$ :

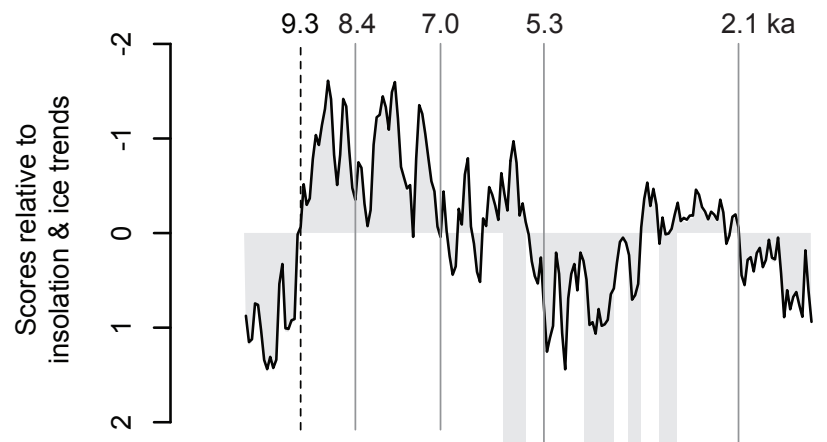

D. PC2 residuals

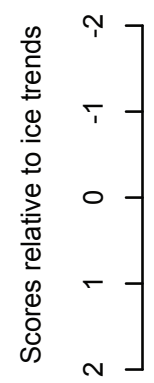

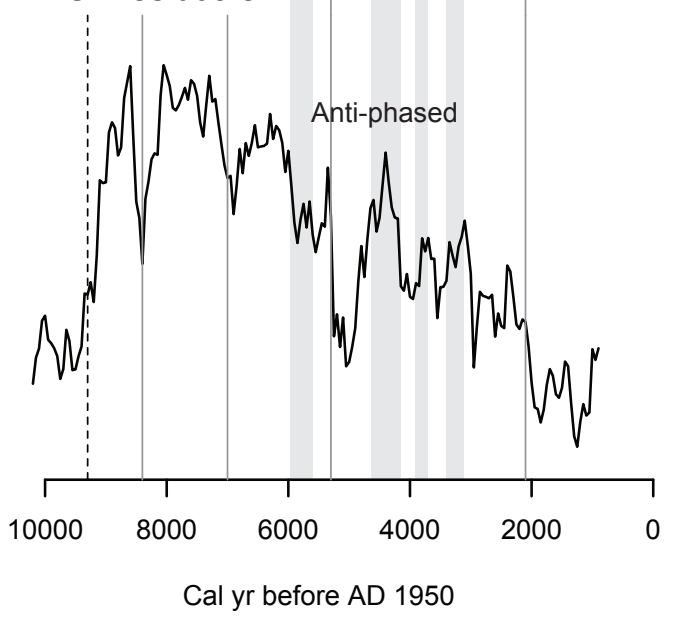



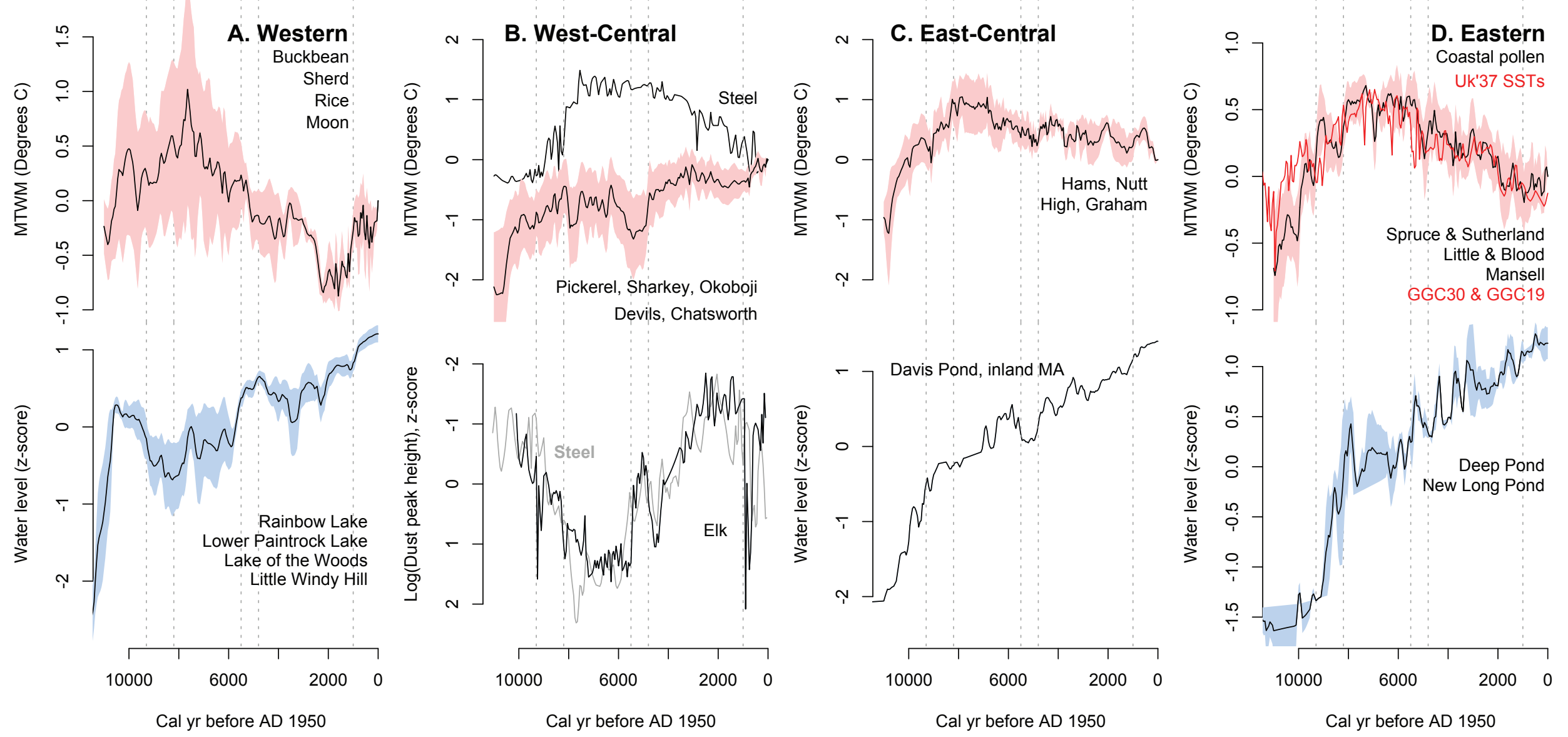


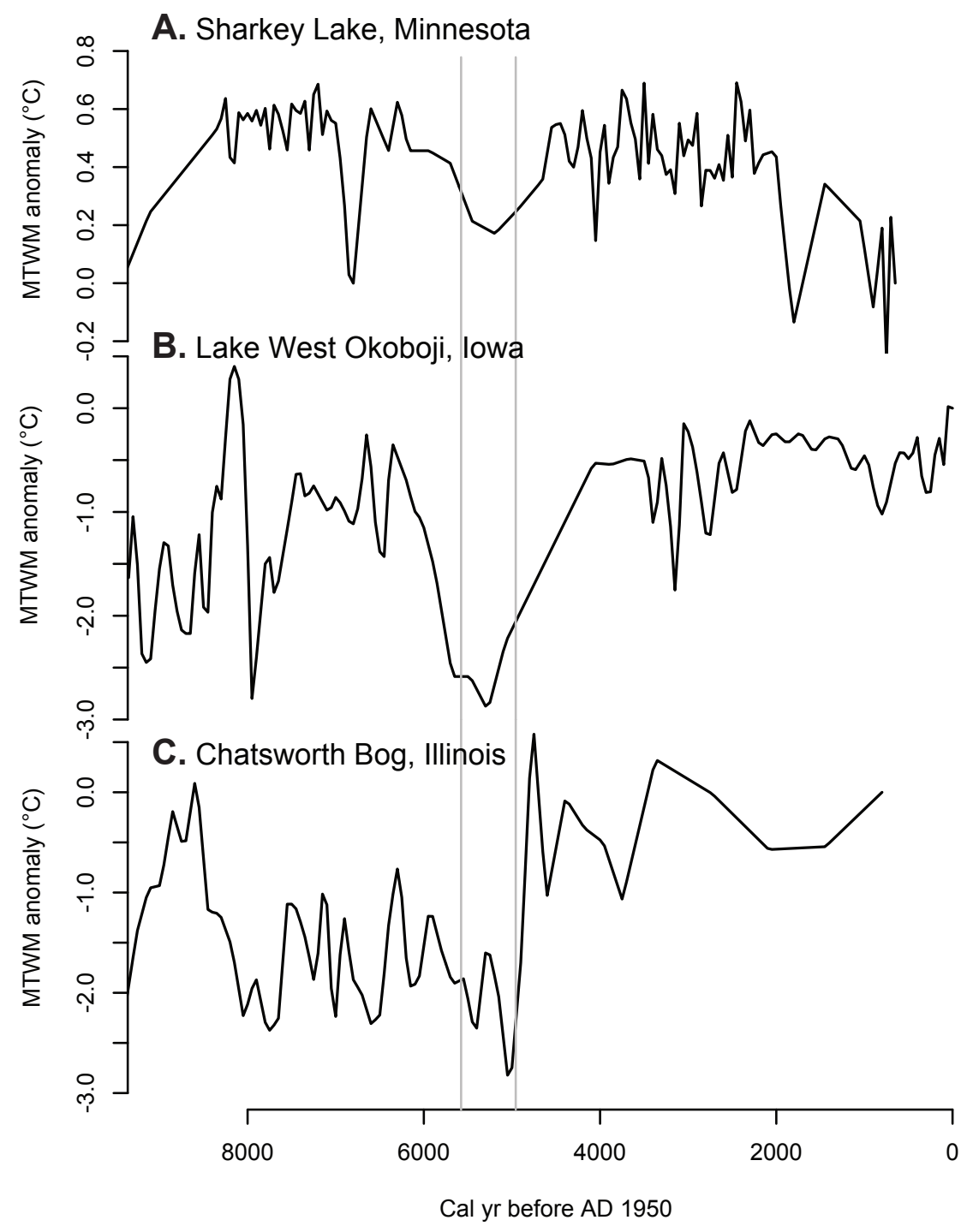




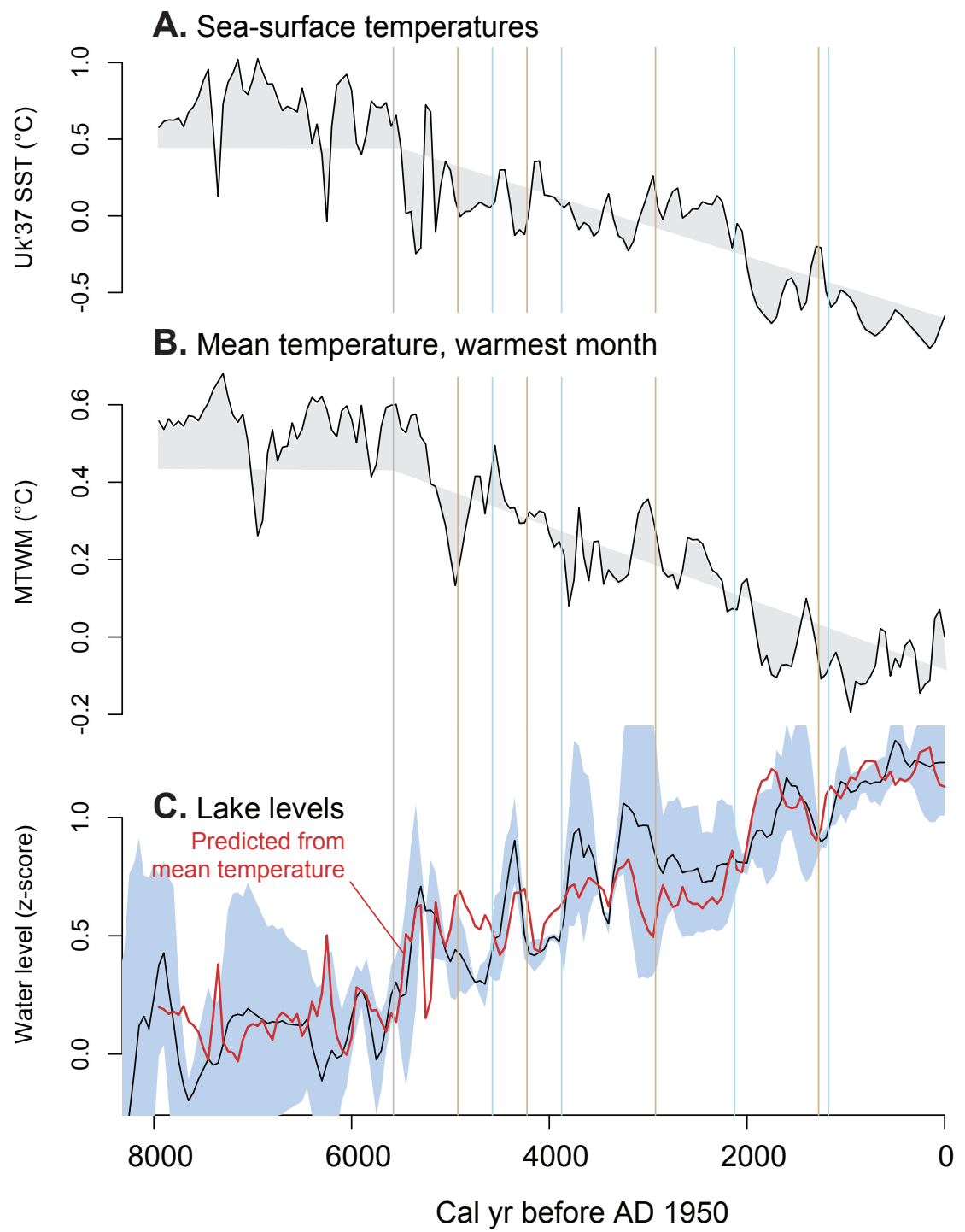

Shuman and Marsicek - Figure 8 